
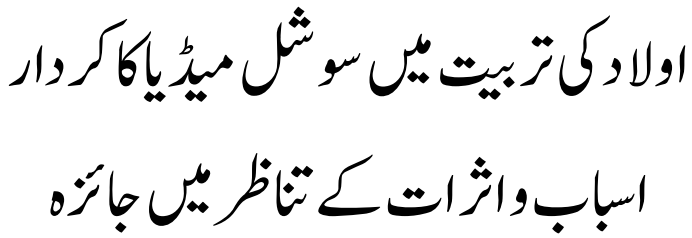

\title{
THE ROLE OF SOCIAL MEDIA IN EDUCATING CHILDREN OVERVIEW IN THE CONTEXT OF CAUSES AND EFFECTS
}

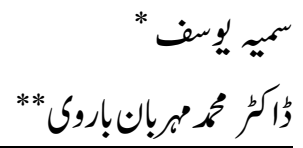

\section{Abstract:}

By training children well, we can lay the foundation for a better society Because children are the architects of the future, if children are trained well from the beginning, a better society can be planned. This topic highlights the potential aspects of child training that are needed today. The title also contains references to the Qur'an and Hadith so that better training can be given in their light and thus the children can be corrected and to unleash their hidden talents. This topic uses points that can be used to refine children's personality. This topic also highlights the technologies used today, with social media topping the list. Social media plays an important role in educating children on how children can benefit from it and How children can benefit from it and how its misuse can lead to harm. Keywords: social media, children, architects, future, Quran, Sunnah, Westren, civilization

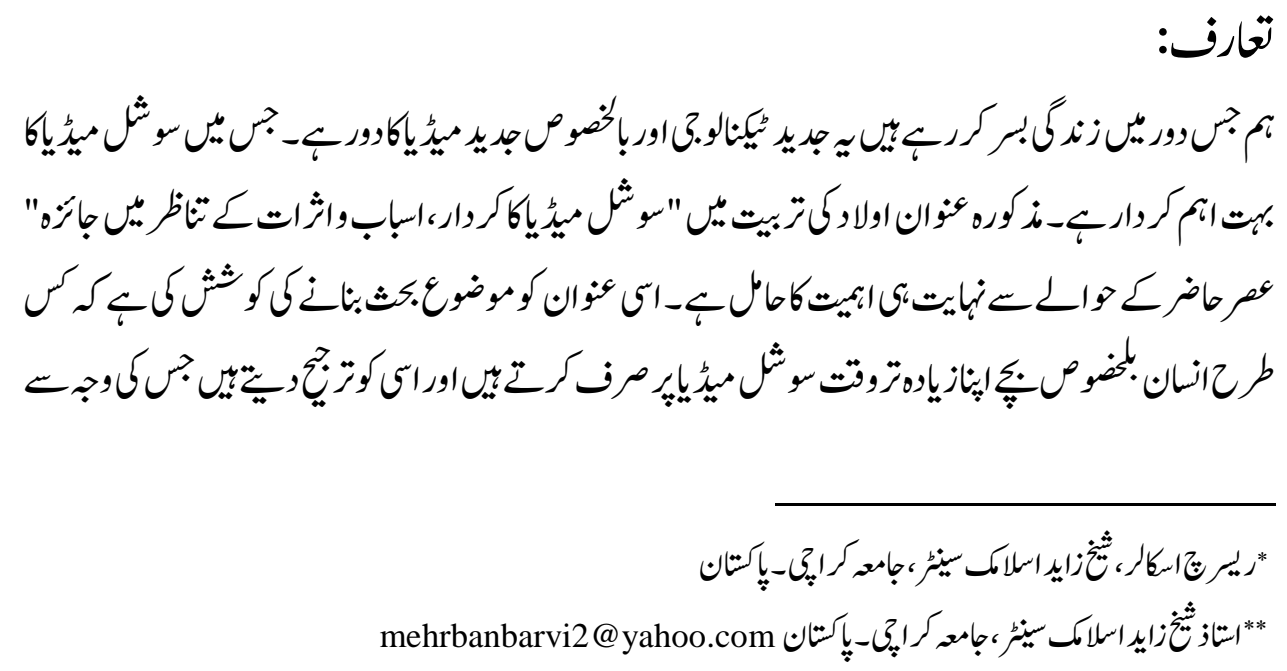




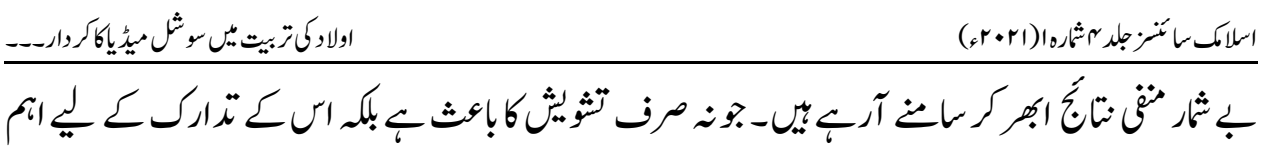
كروار اواكرنكاضن

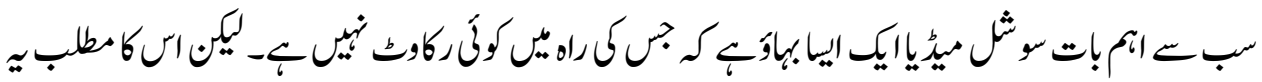

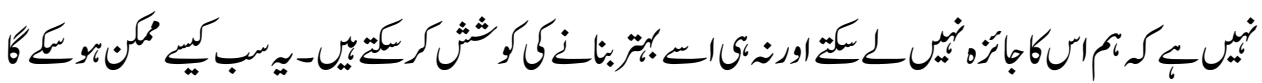

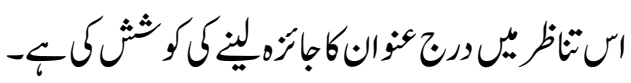

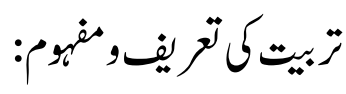

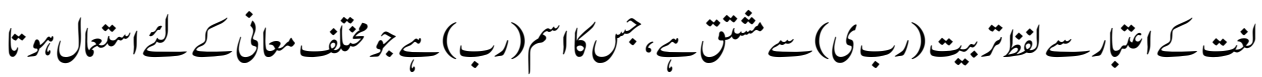

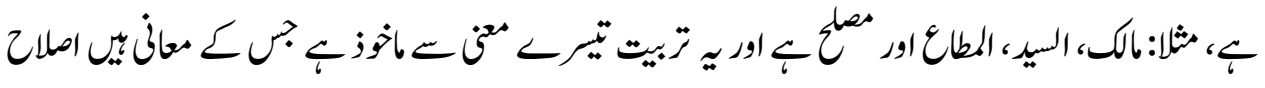

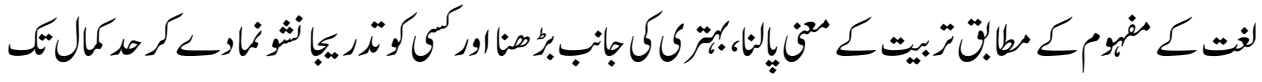

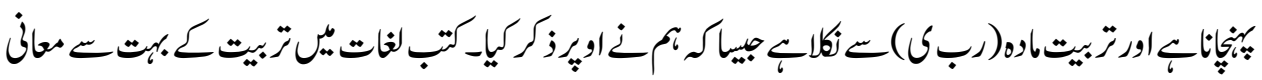

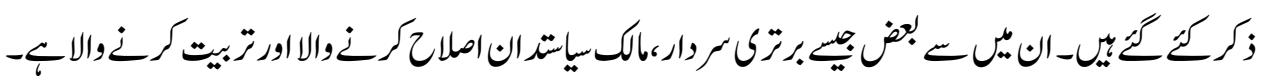

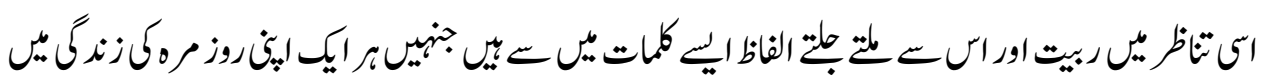

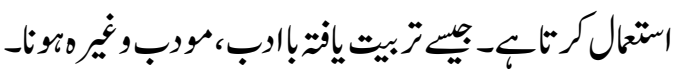

$$
\begin{aligned}
& \text { اصطاح تر ليف: }
\end{aligned}
$$

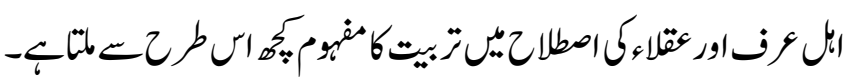

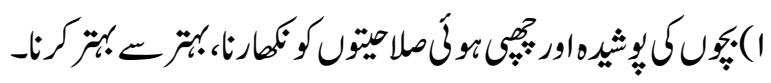

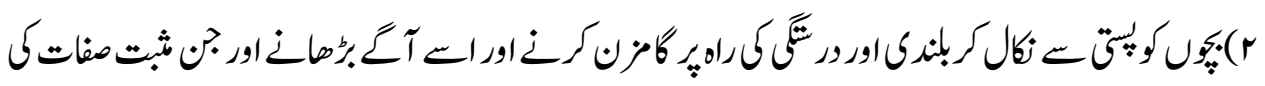

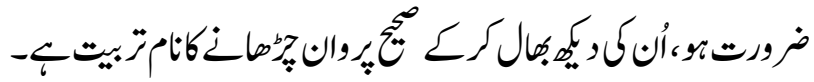

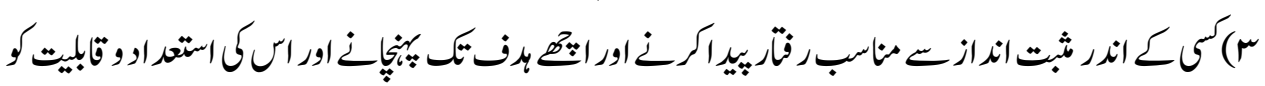

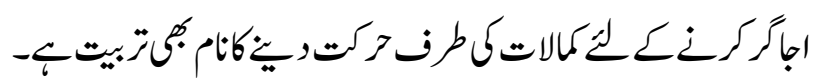

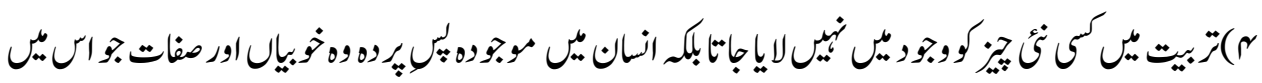

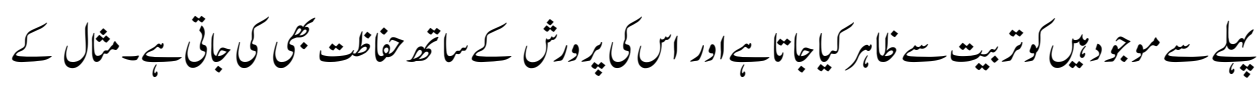




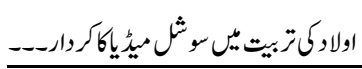

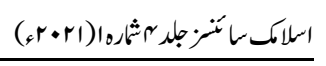

طوريٌ:

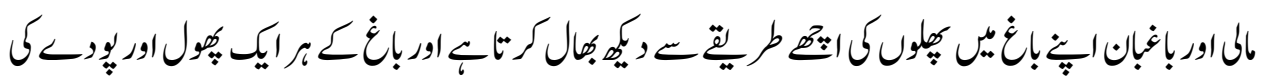

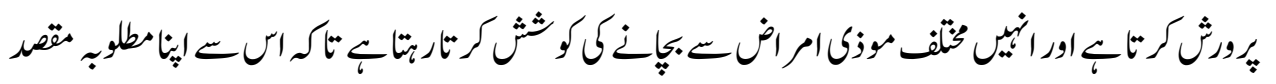

(2)

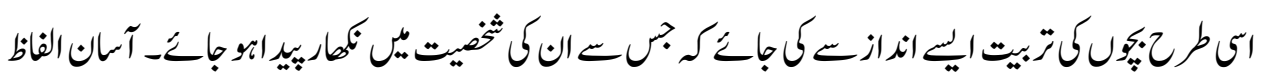

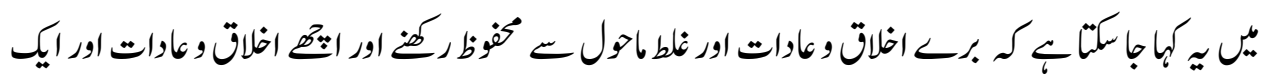

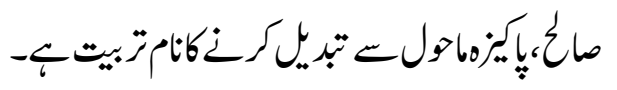

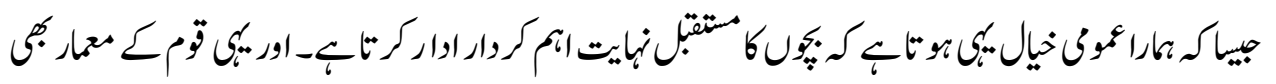

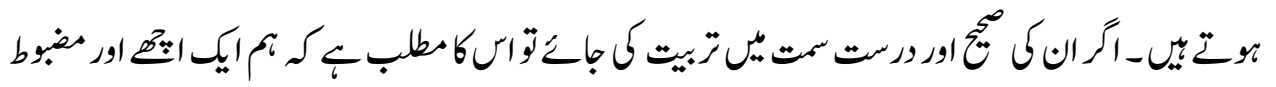

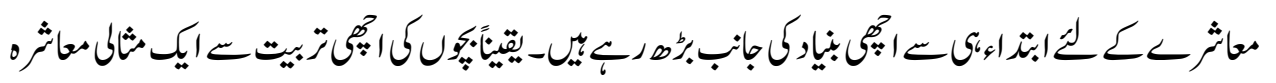

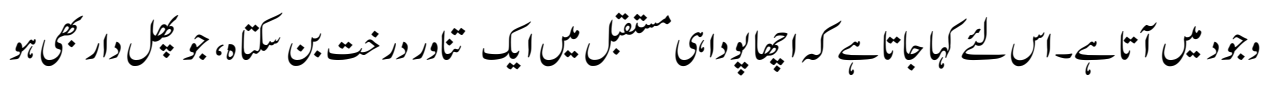

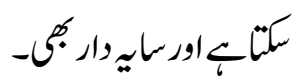

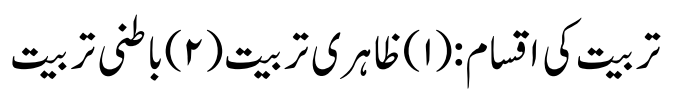

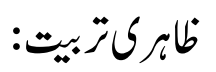

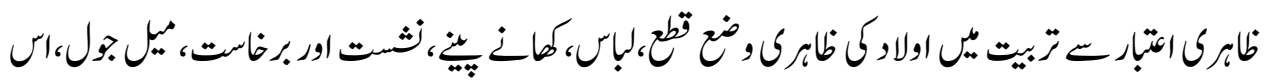

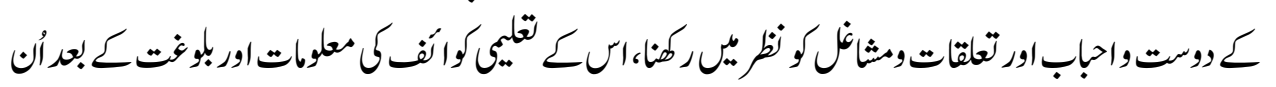

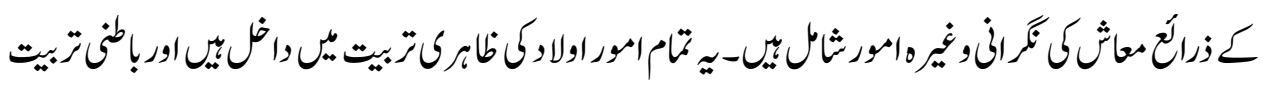

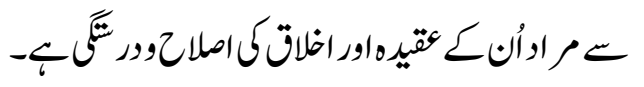

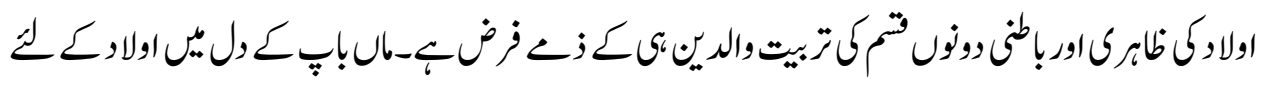

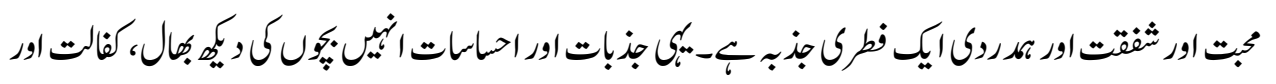

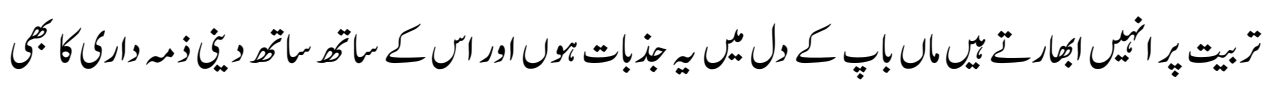

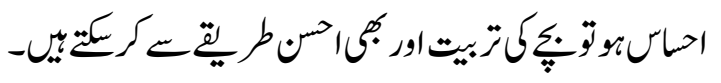

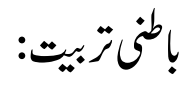




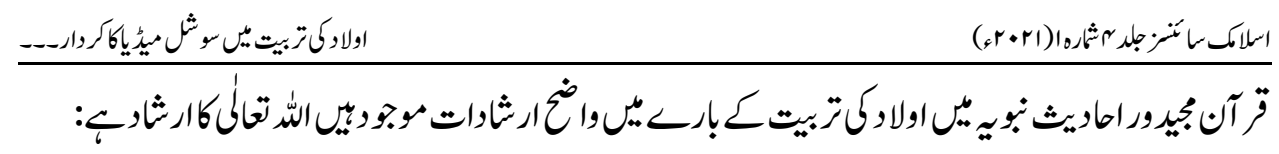

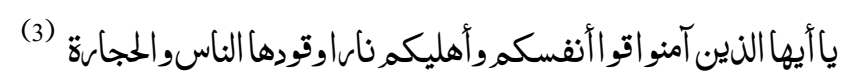

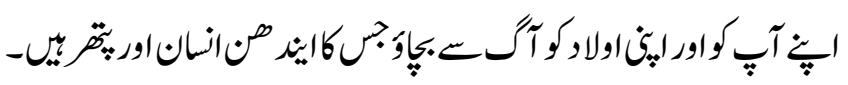

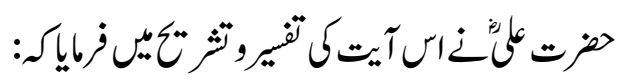

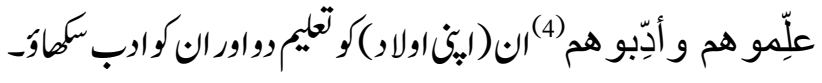

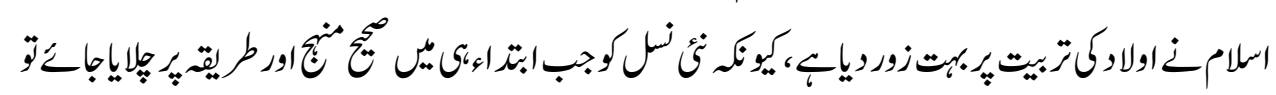

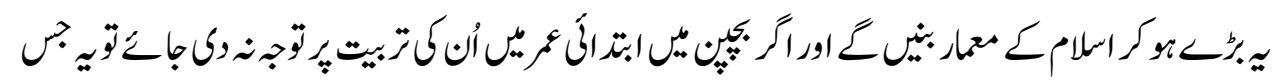

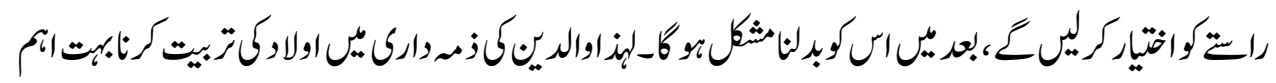

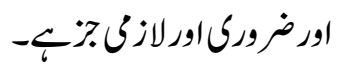

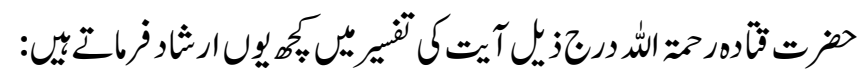

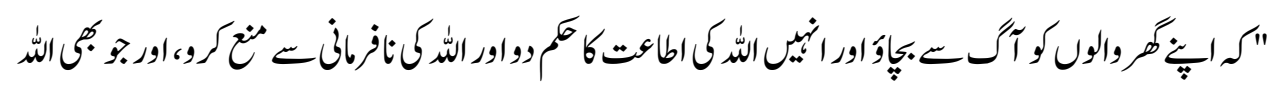

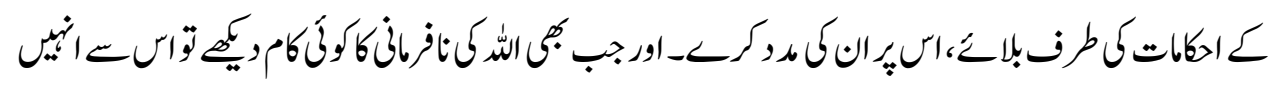

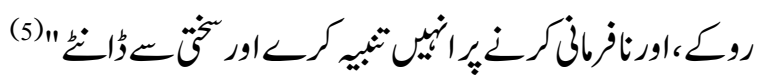

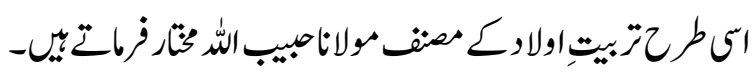

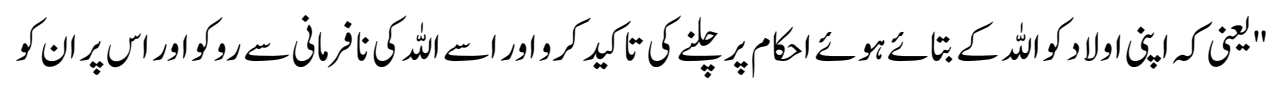

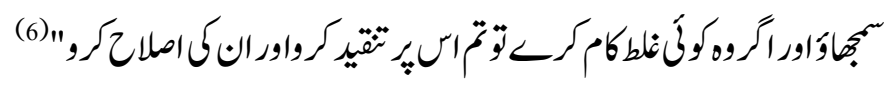

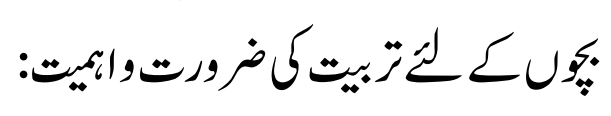

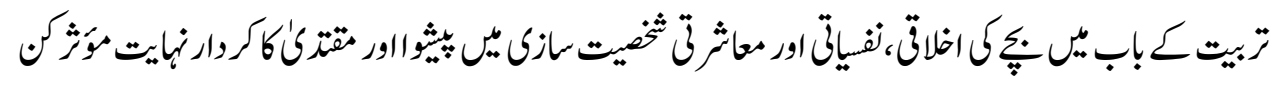

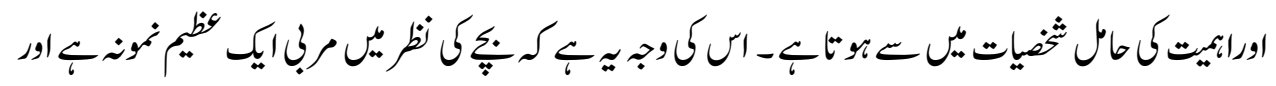

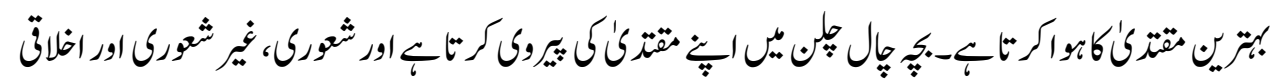

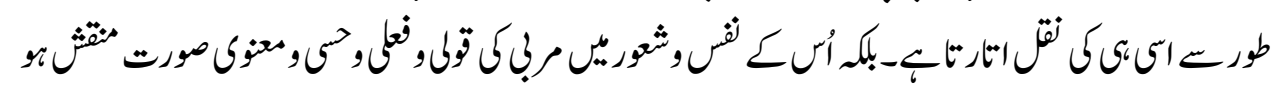

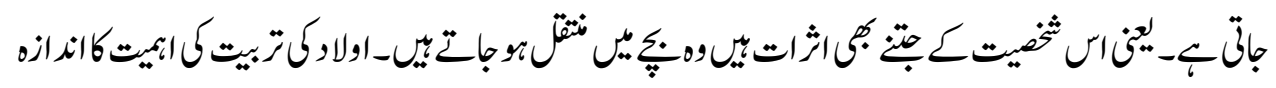

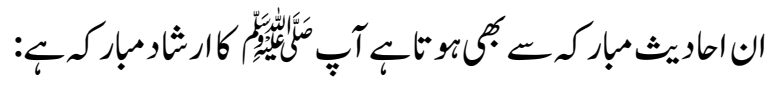




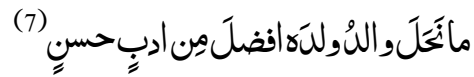

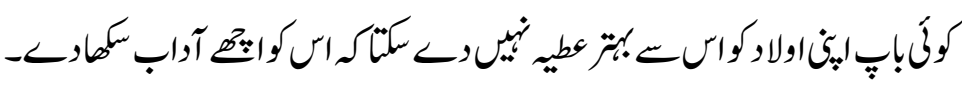

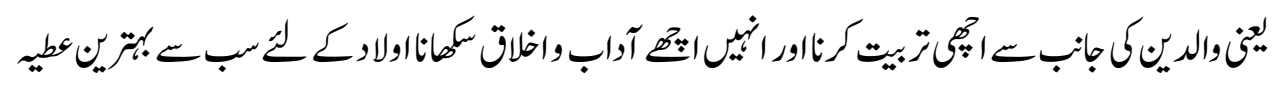

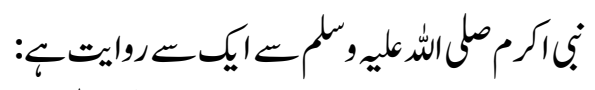

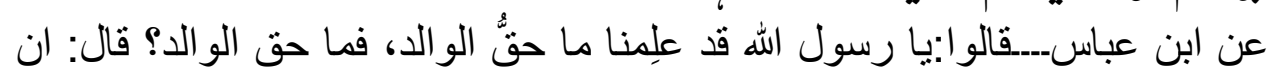

يحسن اسمَح ويحسن ادبـ (8)

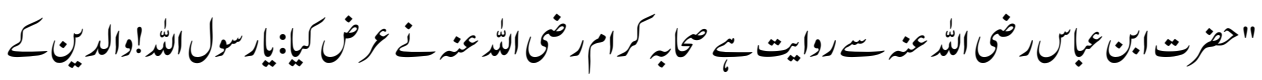

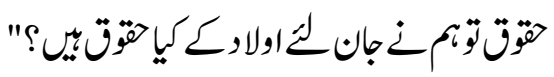

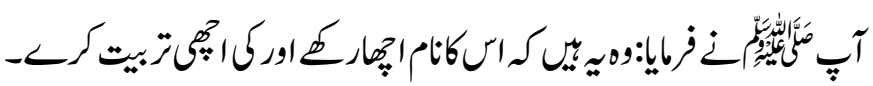

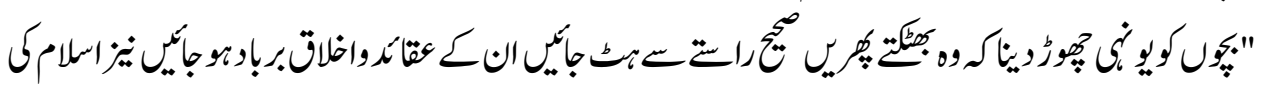

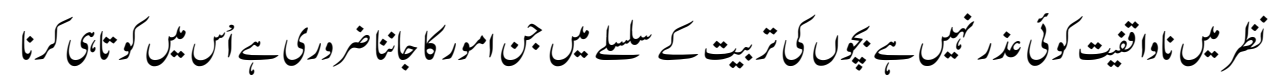

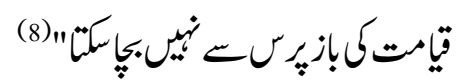

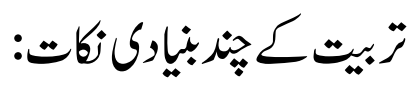

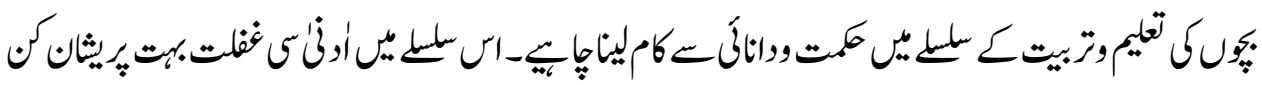

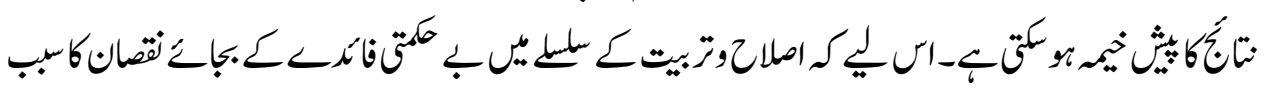

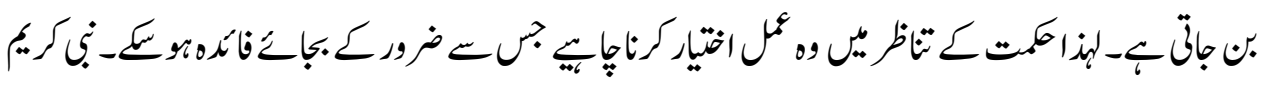

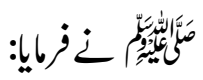

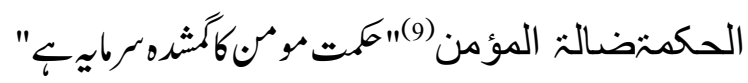

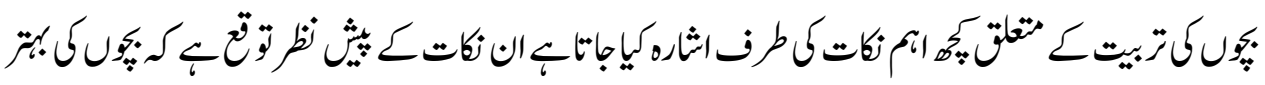
نثونمانو ستك

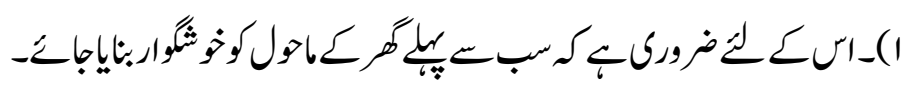

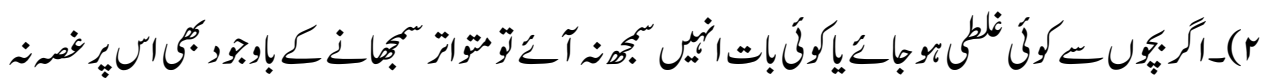

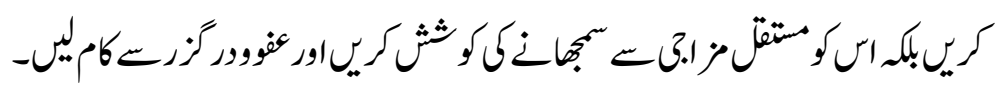




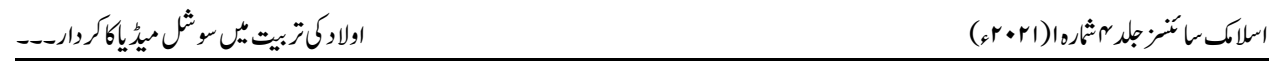

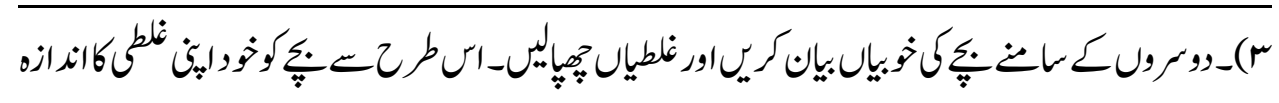
cو

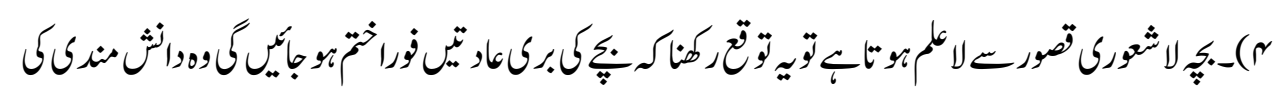

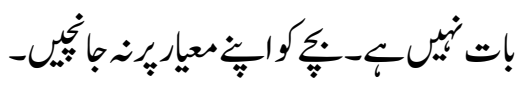

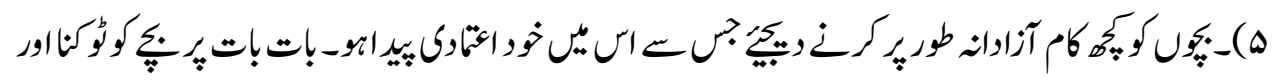

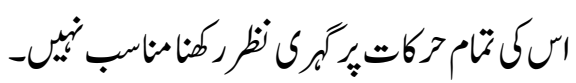

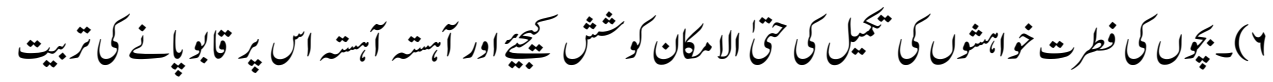

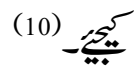

$$
\begin{aligned}
& \text { نيولكاتزبيت ع الممهيهو: } \\
& \text { اخلاقت تبيت: }
\end{aligned}
$$

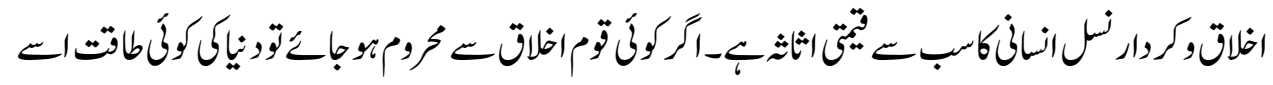

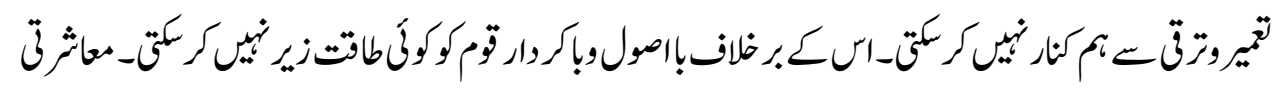

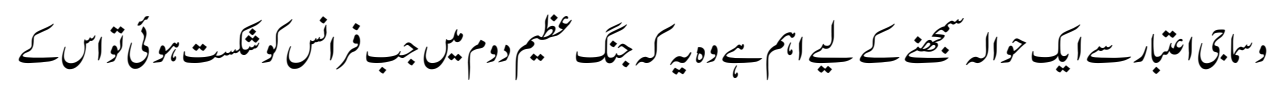

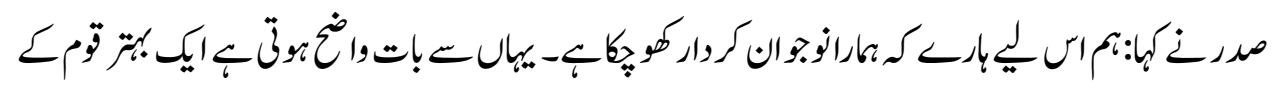

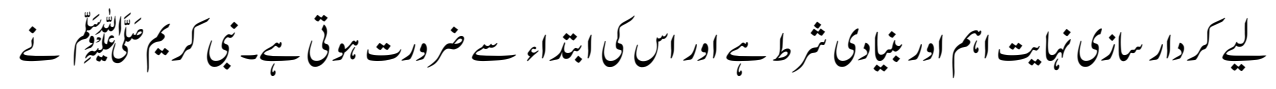

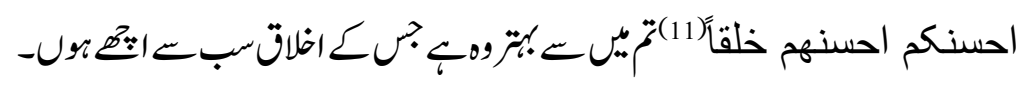

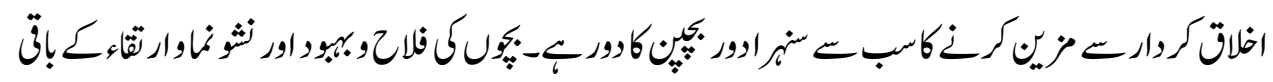

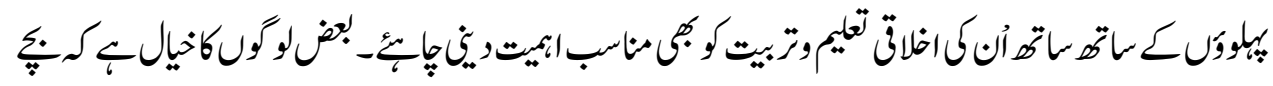

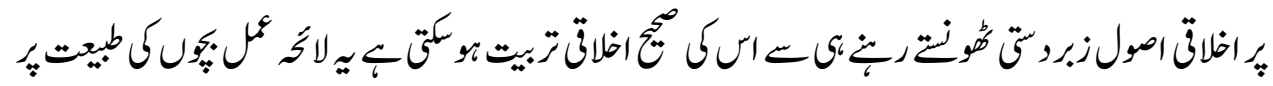

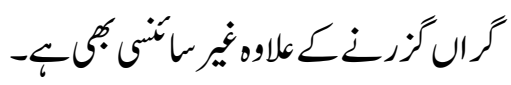

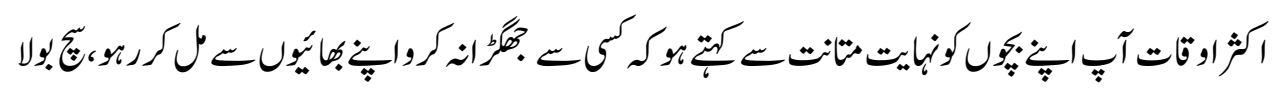

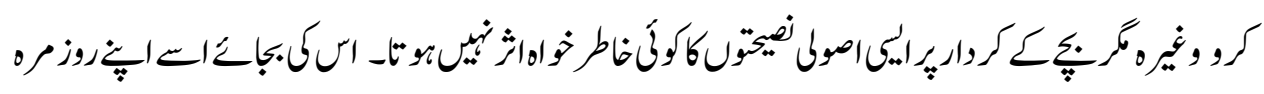




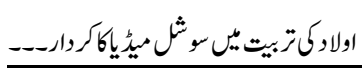

(arri)

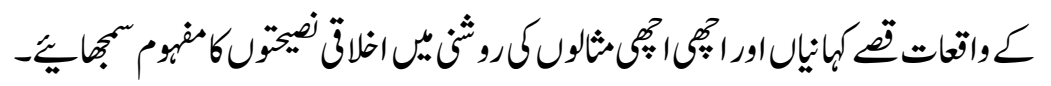

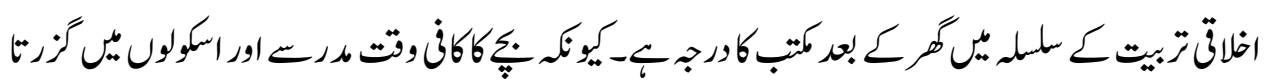

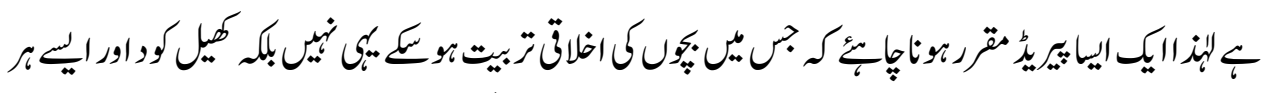

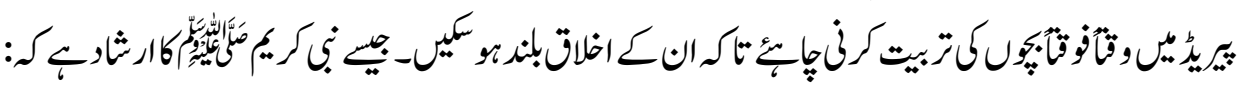

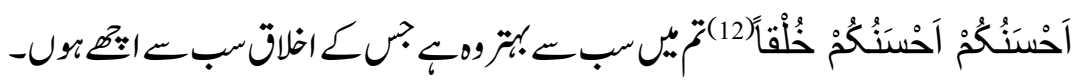

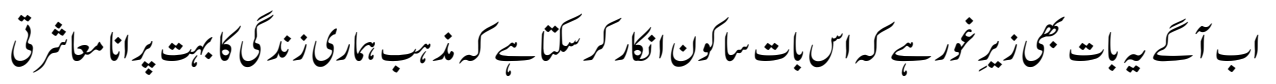

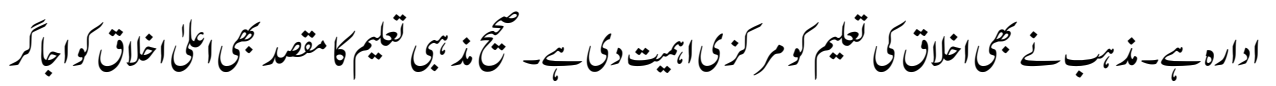

كرنبان

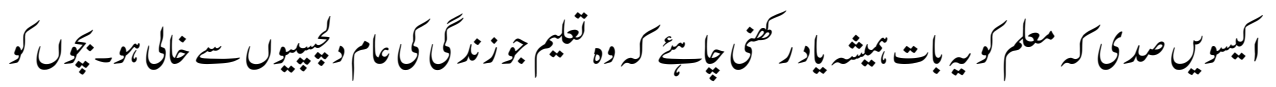

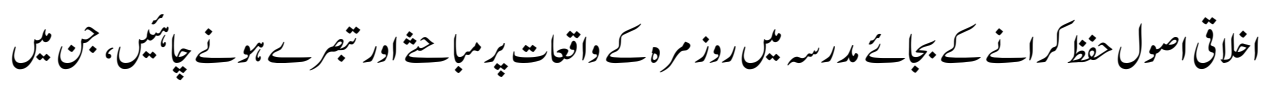

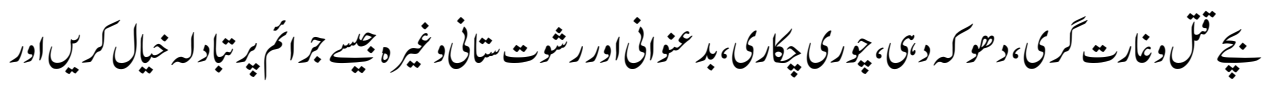

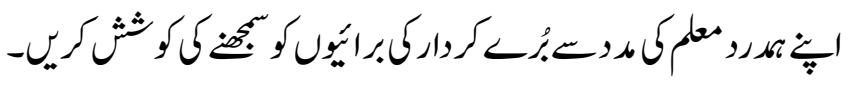

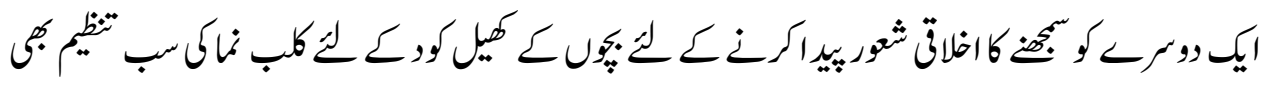

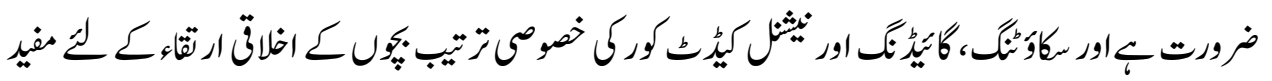

${ }^{(13)}-4$

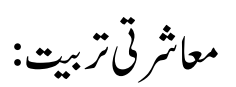

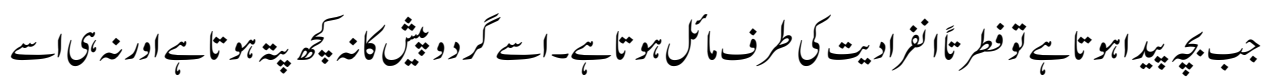

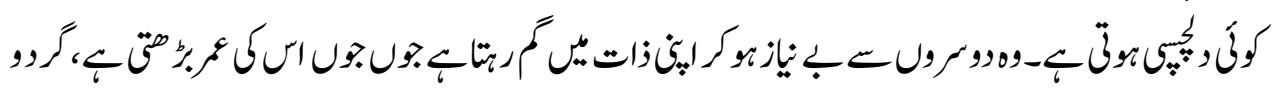

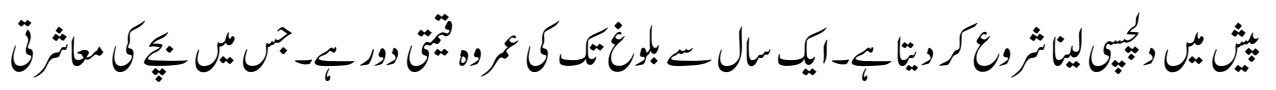

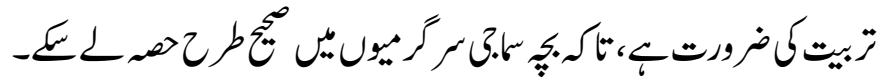

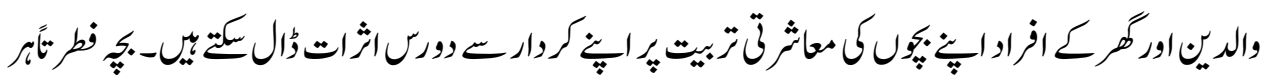

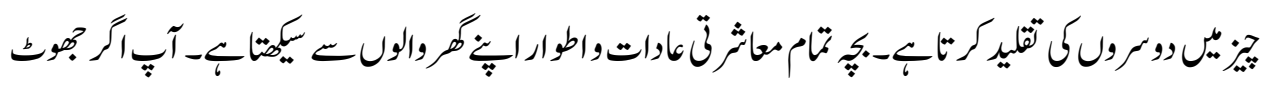

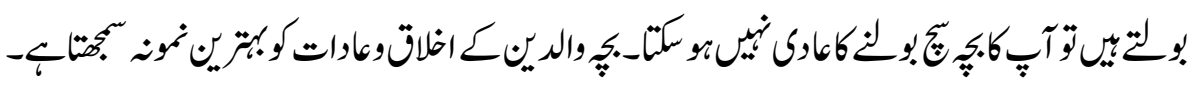

98 


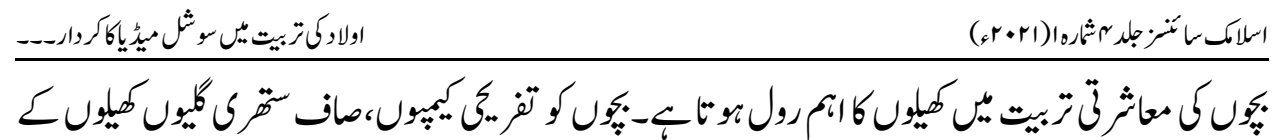

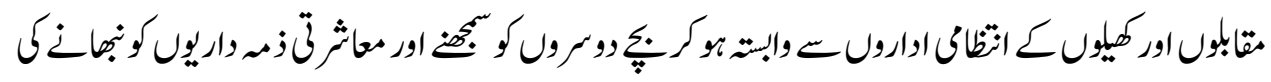

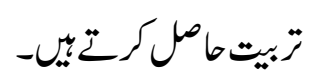

; زبنثزبيت:

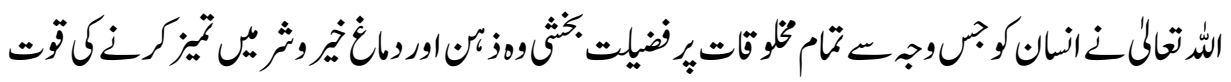

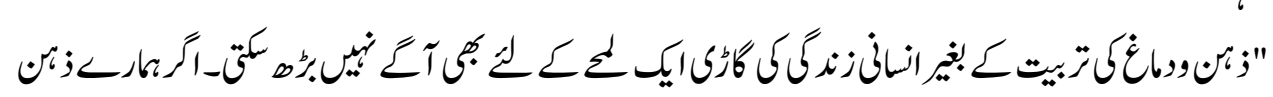

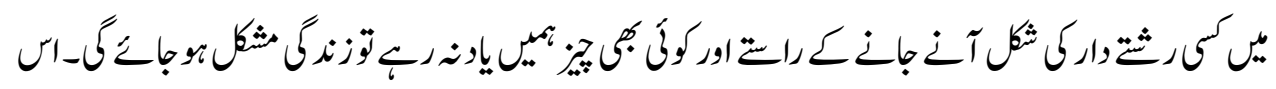

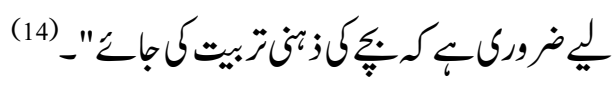

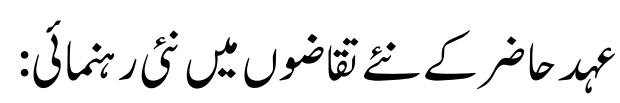

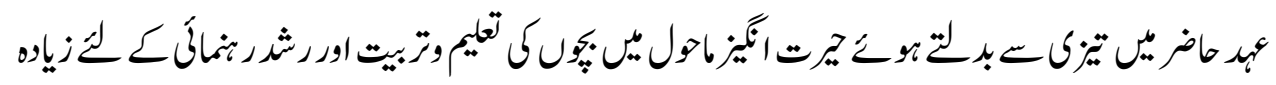

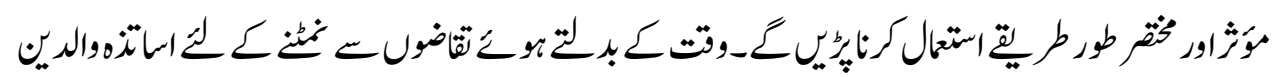

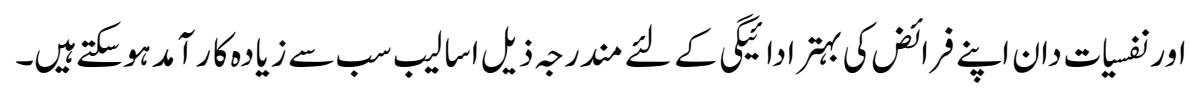

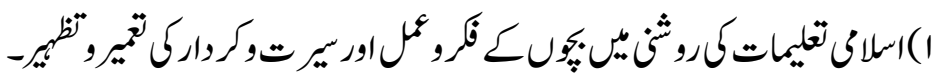

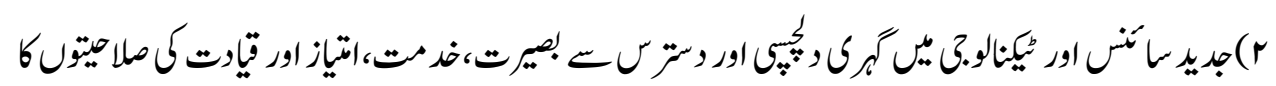
زو

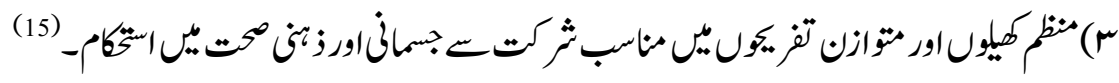

$$
\begin{aligned}
& \text { سوثل ميدياك اثرات } \\
& \text { سوش مئياكك تر ليف: }
\end{aligned}
$$

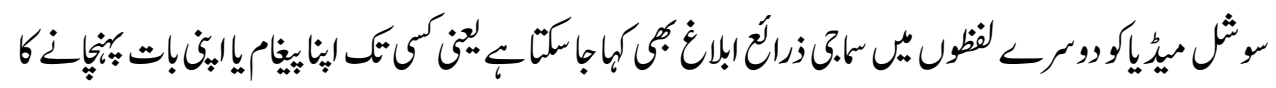

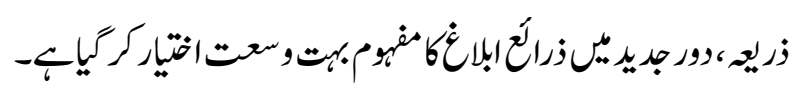
ابلاغ 


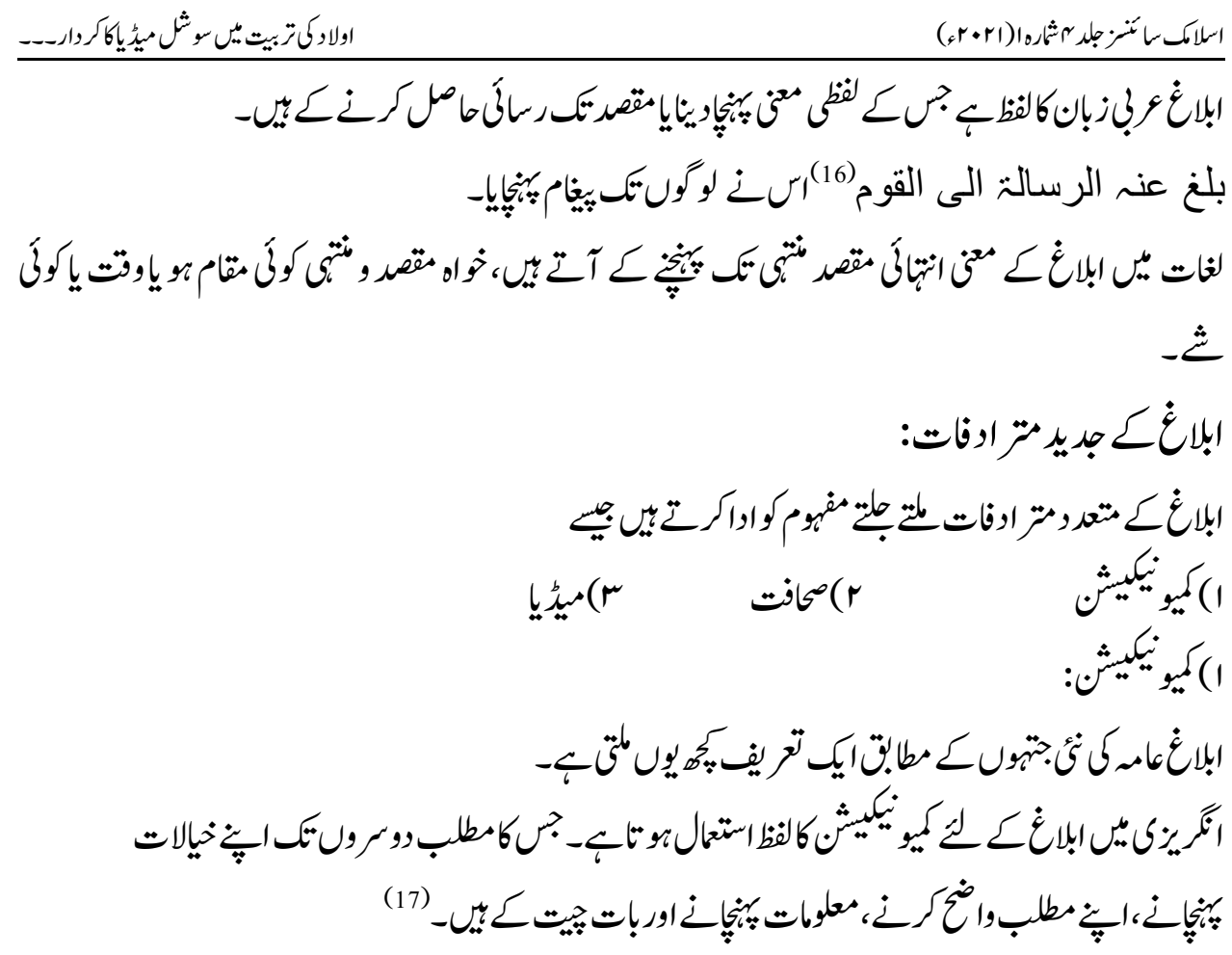
Communication is an act of transmitting ideas, attitudesand information from one person to another. ${ }^{(18)}$

$$
\text { (r }
$$

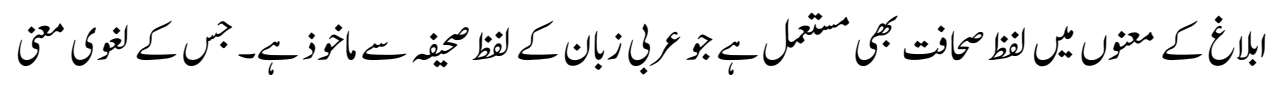

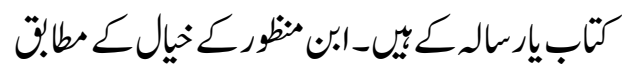

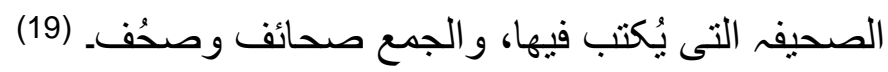

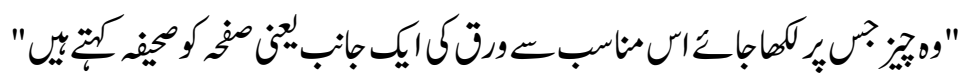

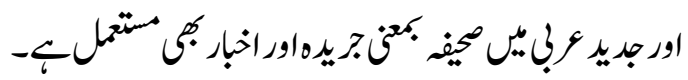

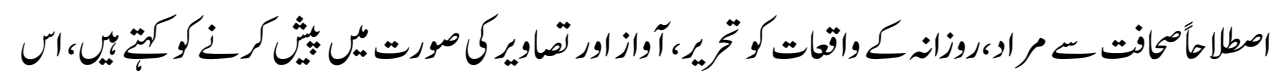

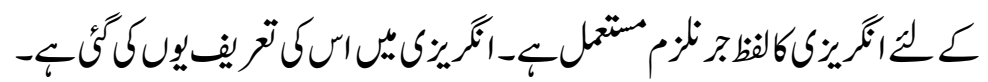
Journalism is the collection of Perrodical publishing of current news. It was confied for centuries to newspaper and magzines. ${ }^{(20)}$ 


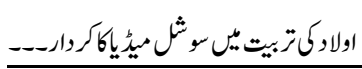

(a)

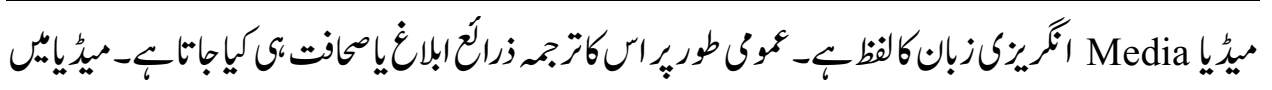

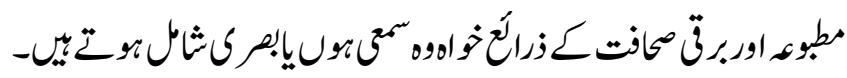

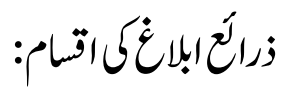

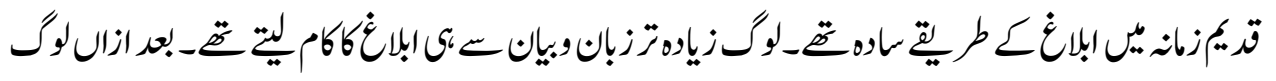

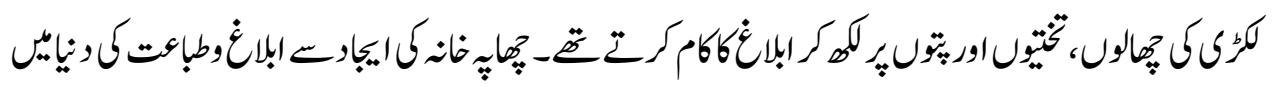

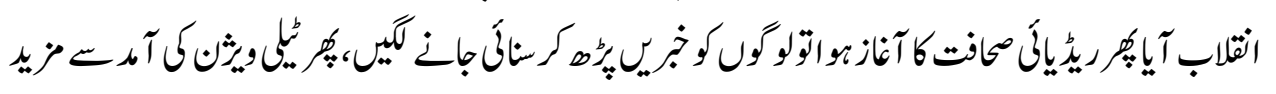

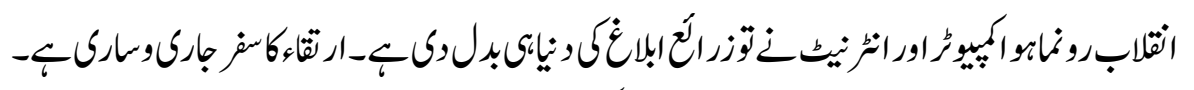

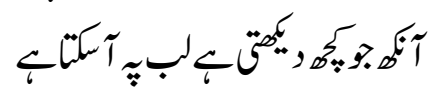

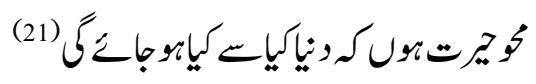

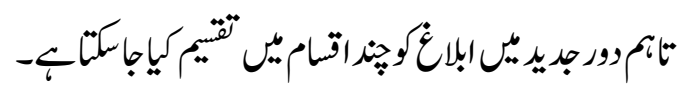

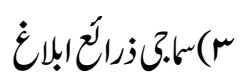

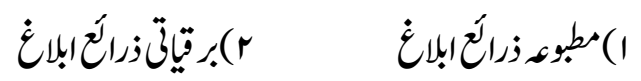

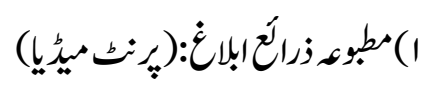

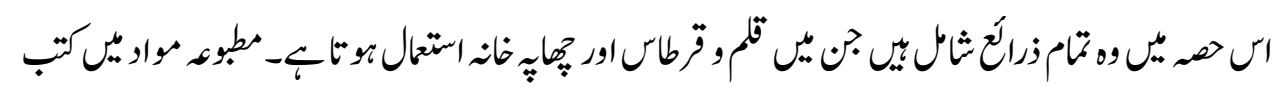

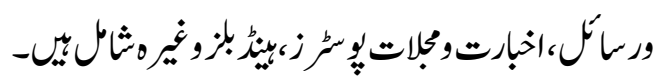

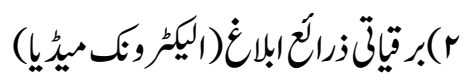

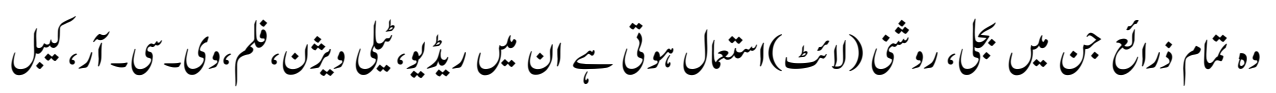

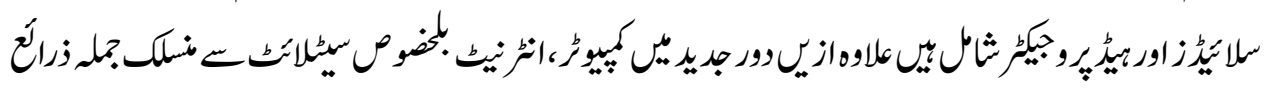

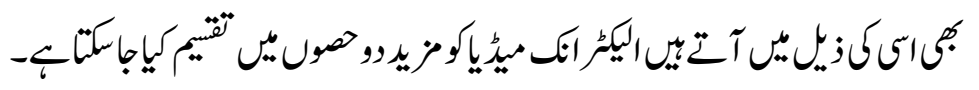

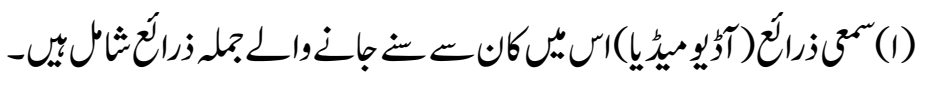

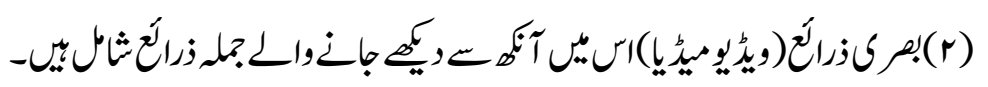

(r)

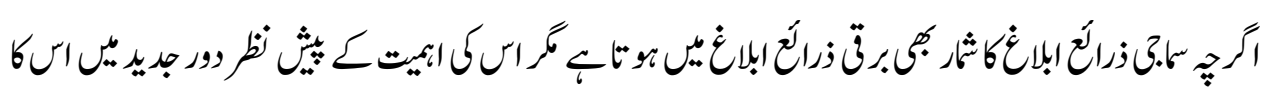

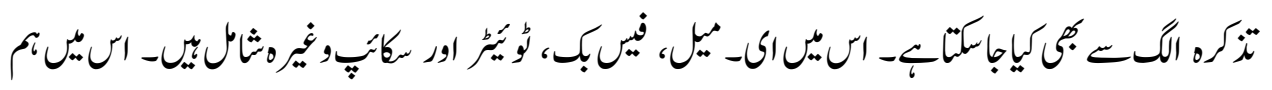

101 


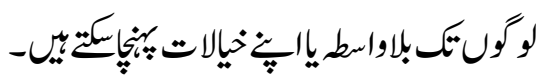

$$
\begin{aligned}
& \text { اسلام هي سوشل ميدُياكانيميت: }
\end{aligned}
$$

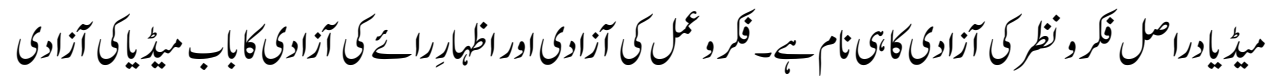

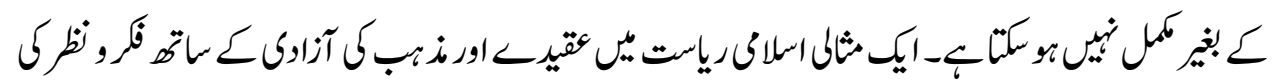

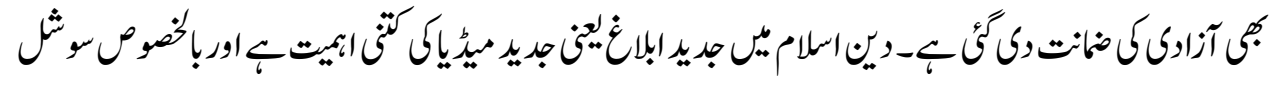

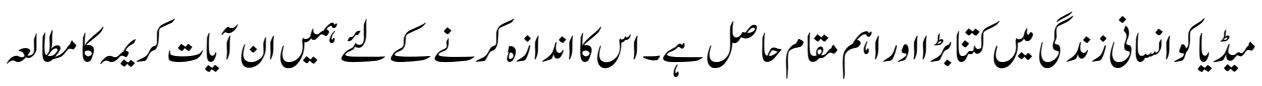

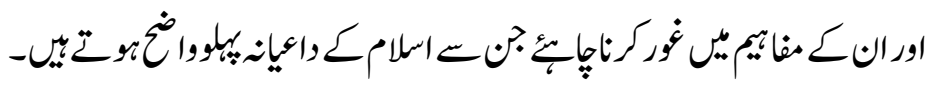

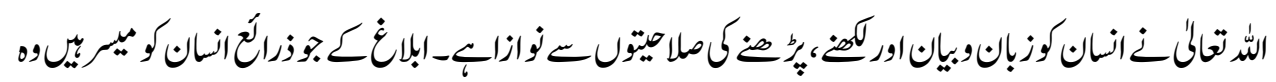

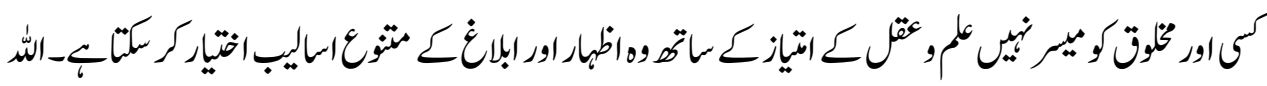
تخالفارشارب:

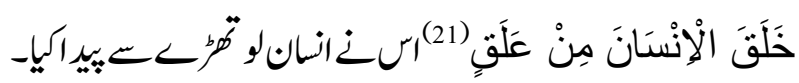

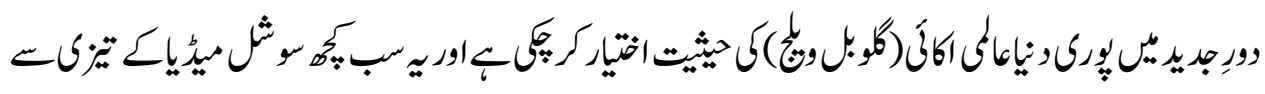

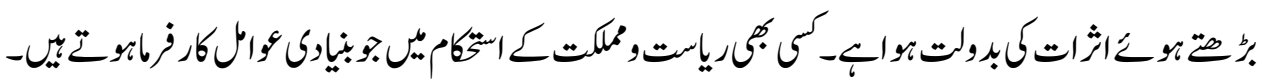

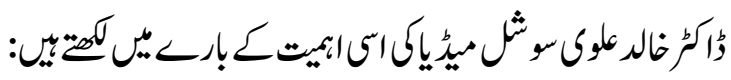

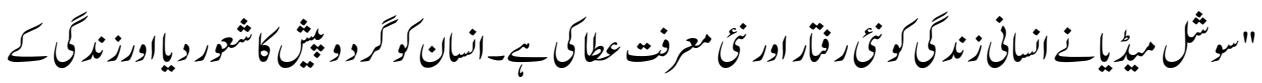

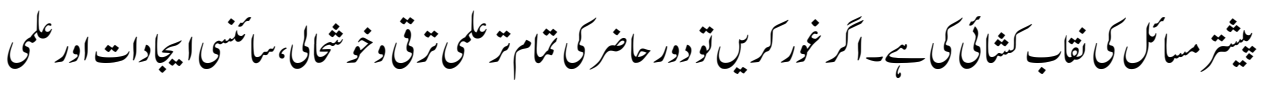

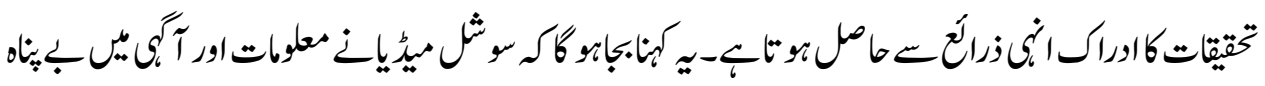

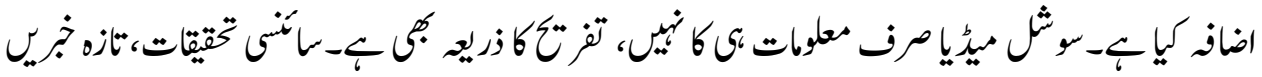

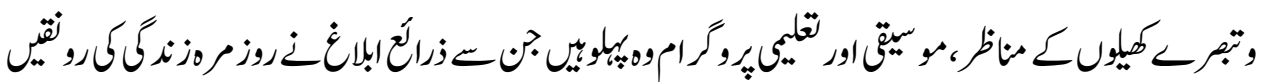

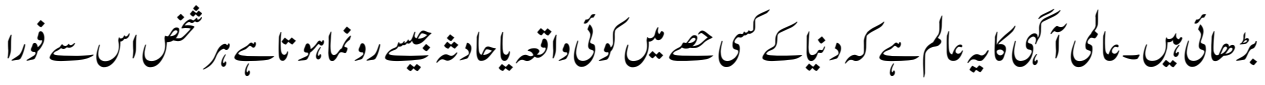

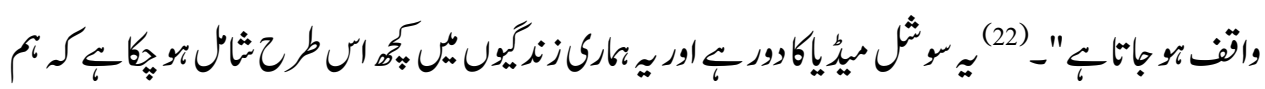

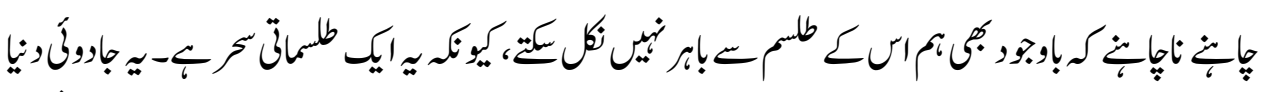

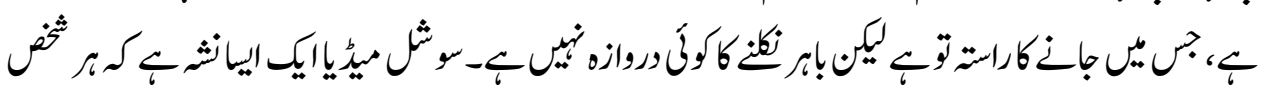

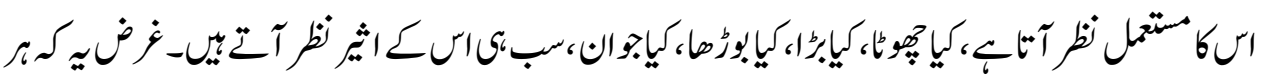




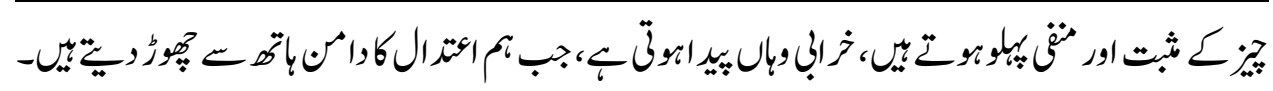

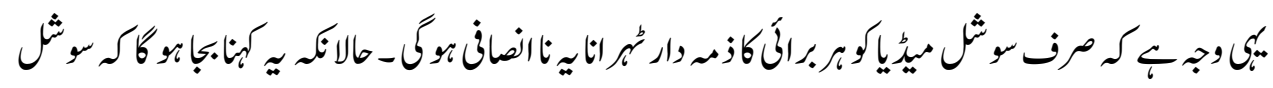

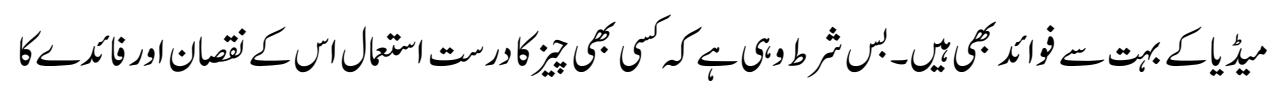

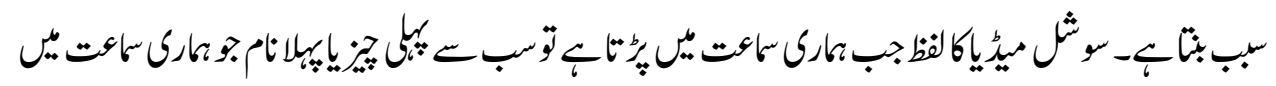

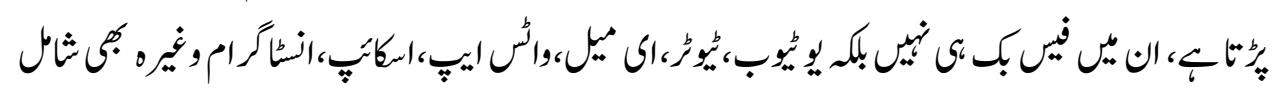

ث.

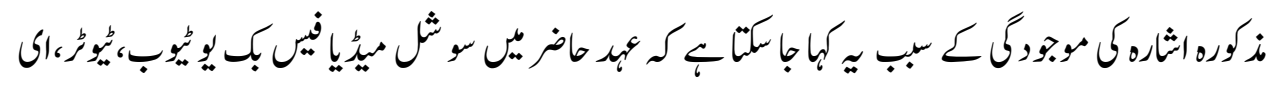

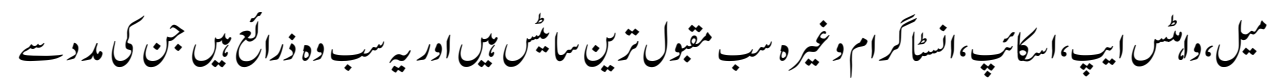

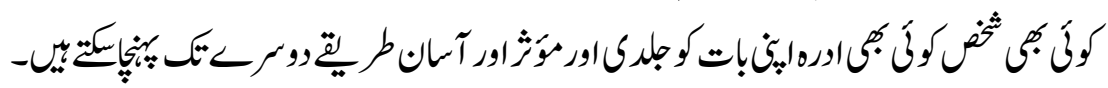

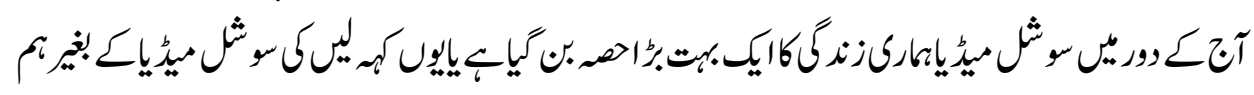

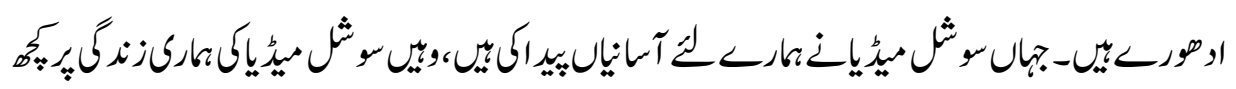

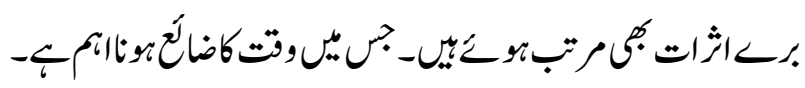

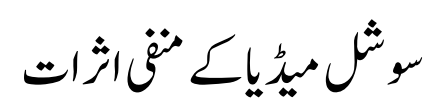

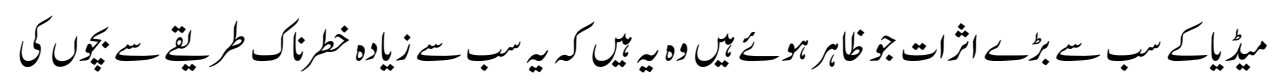

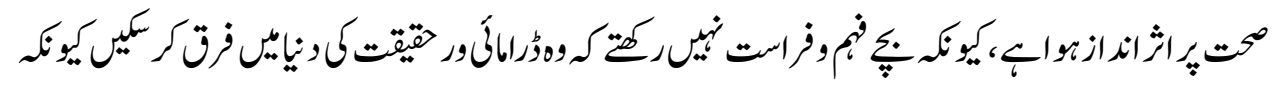

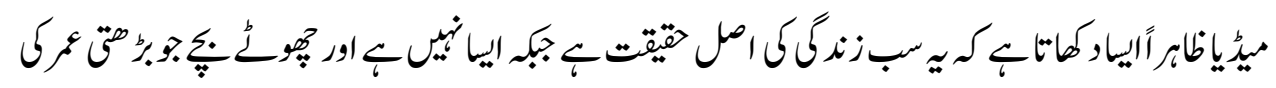

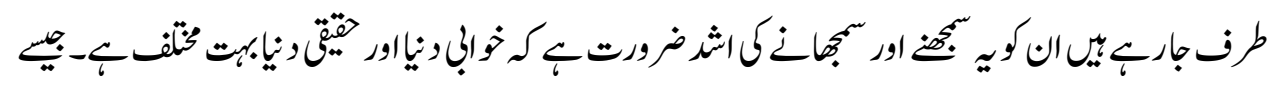

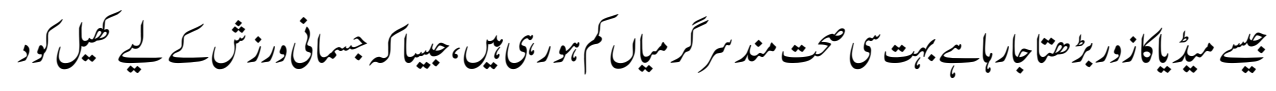

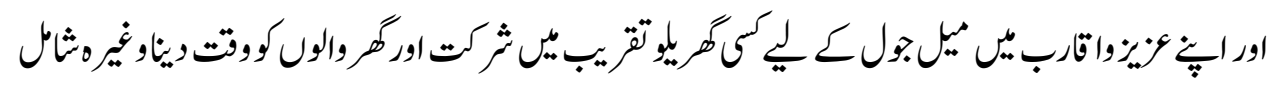

$-4$

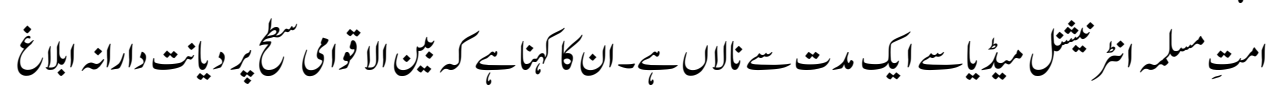

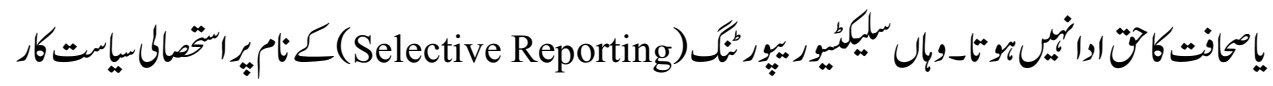

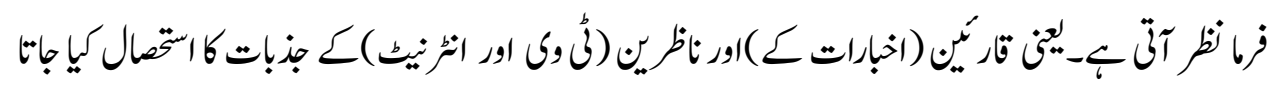




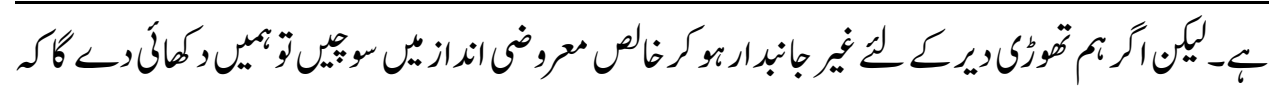

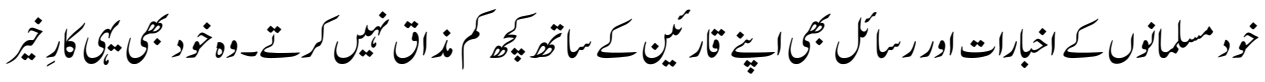

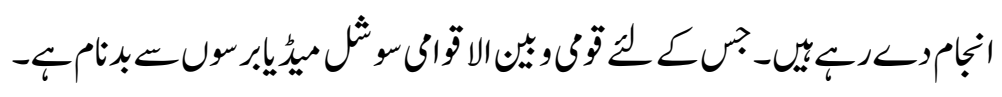

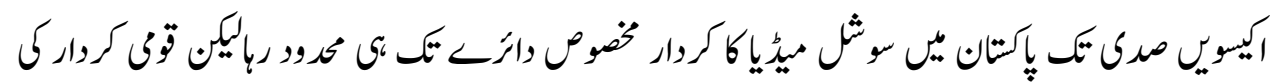

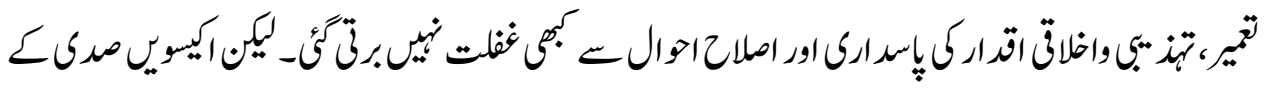

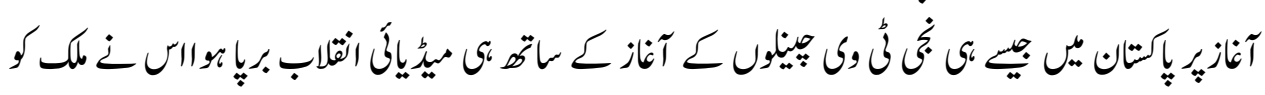

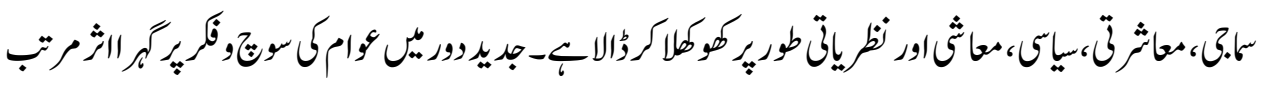

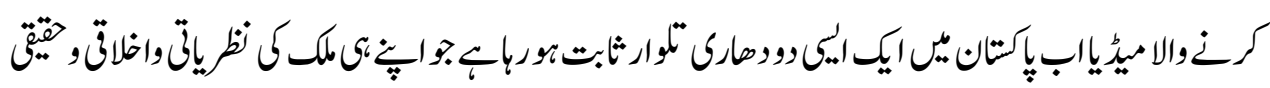

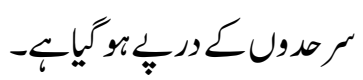

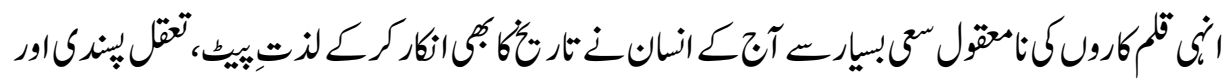

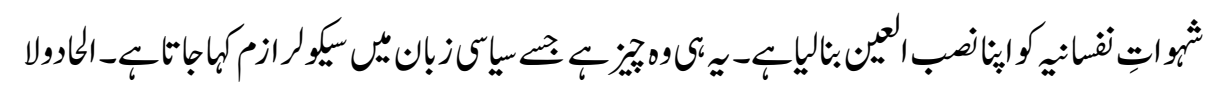

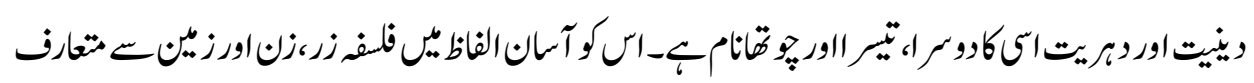

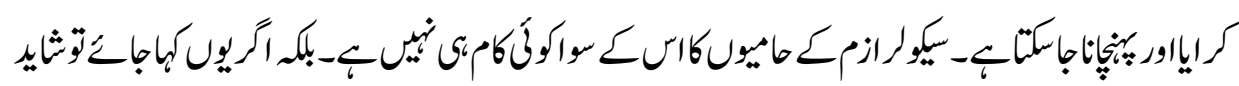

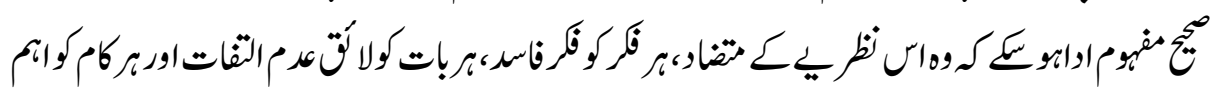

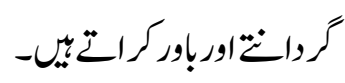

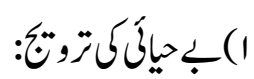

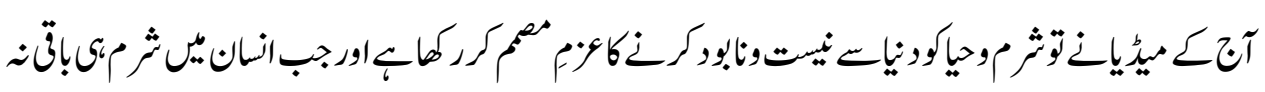

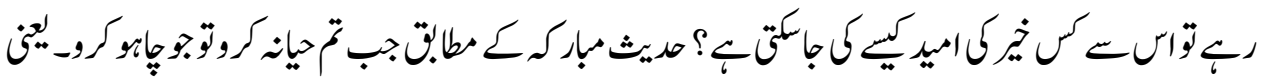

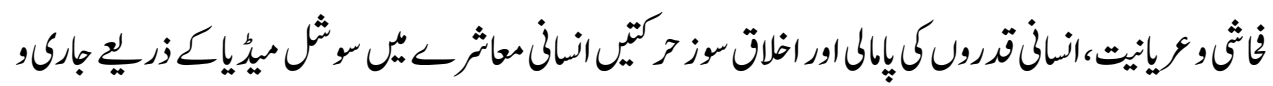

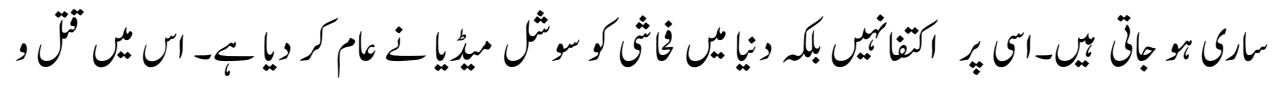

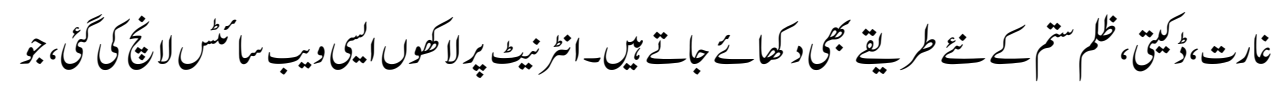

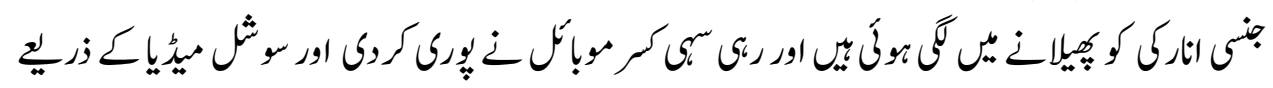

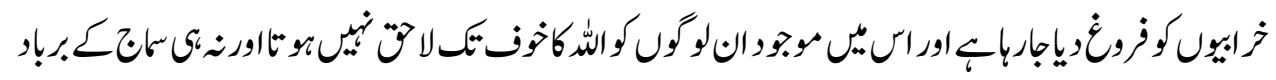

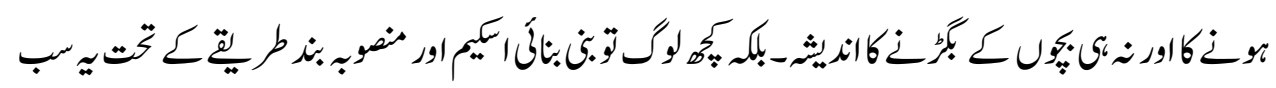




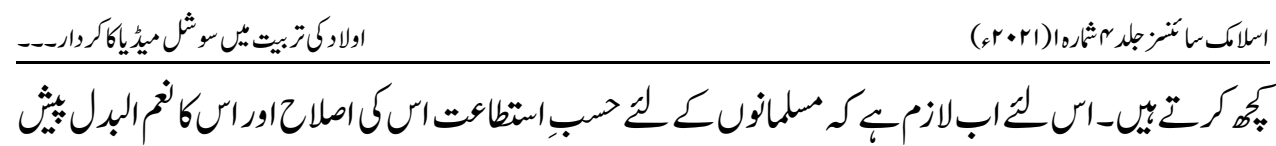

r) ماثرث قانتثترا:

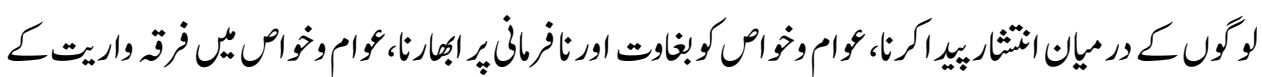

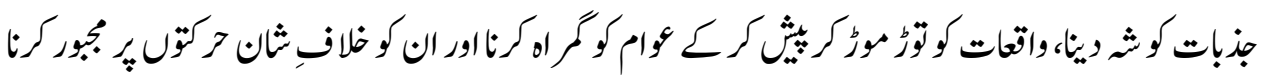

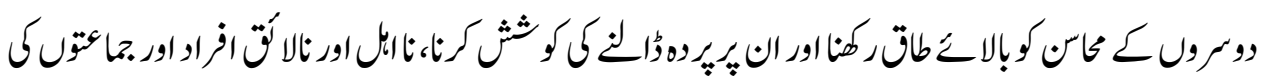

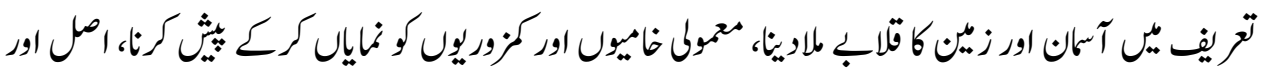

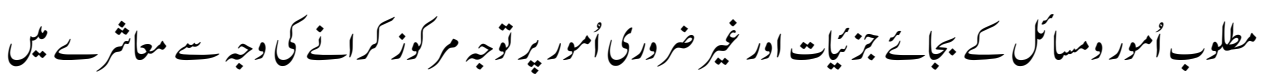

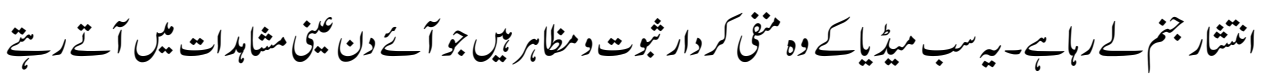

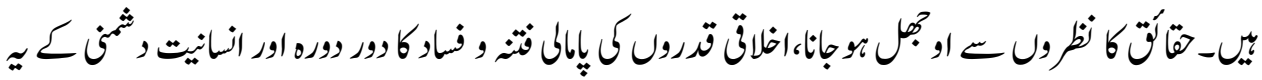

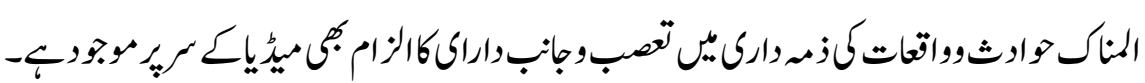
( )

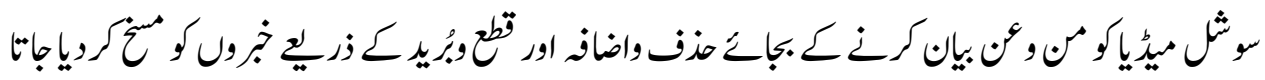

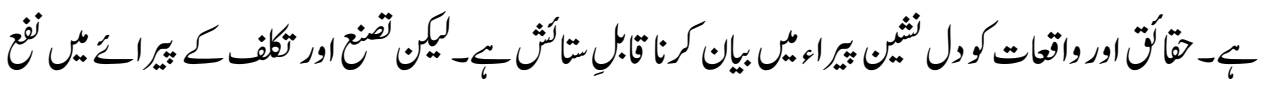

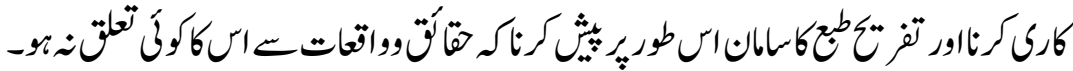
(4)

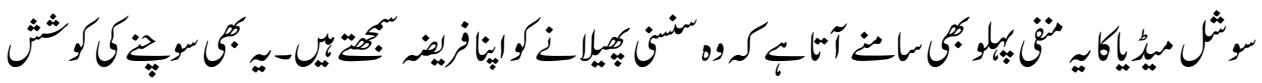

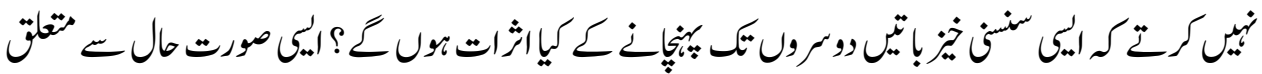

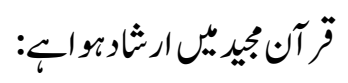

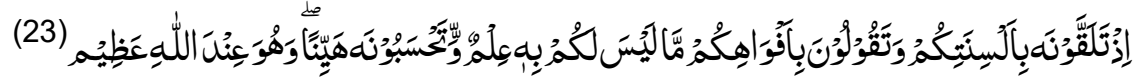

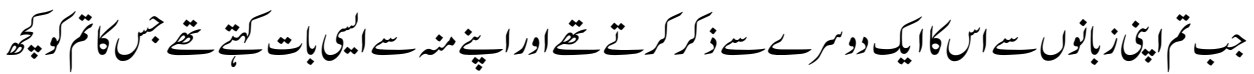

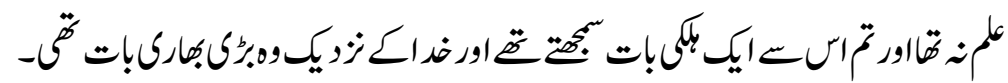

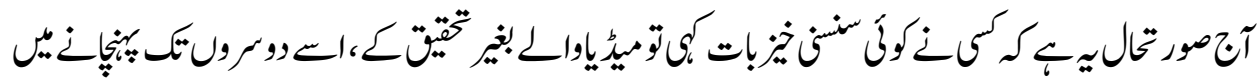

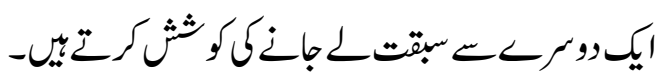




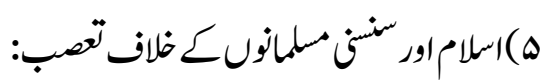

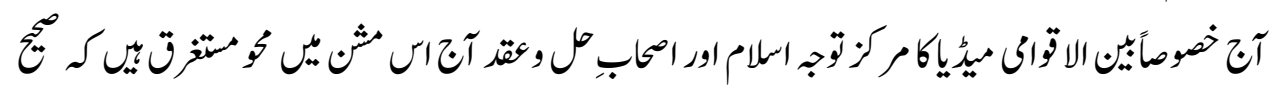

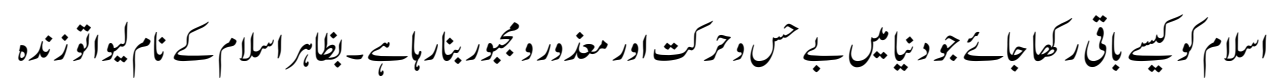

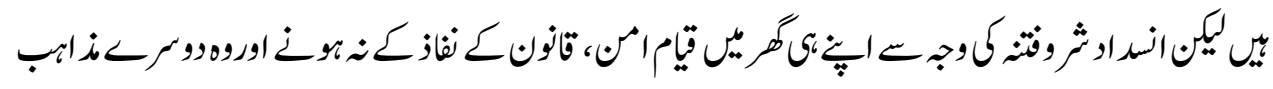

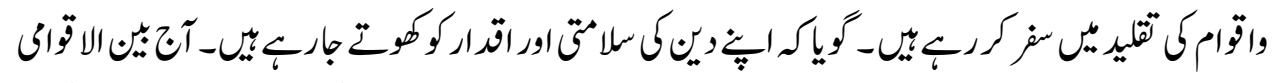

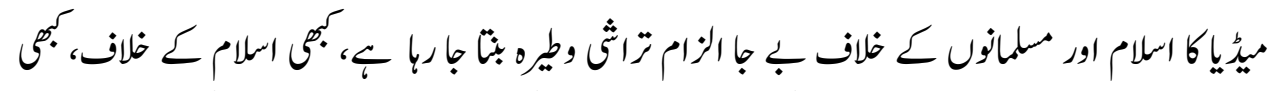

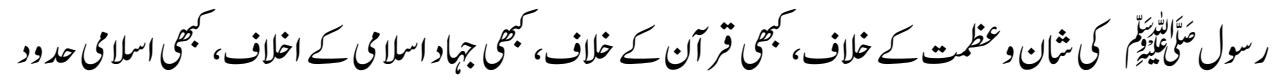

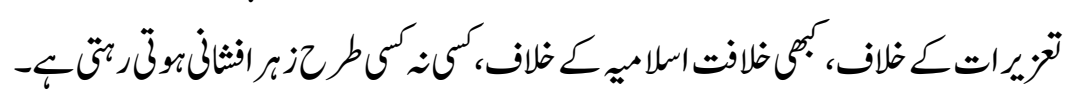

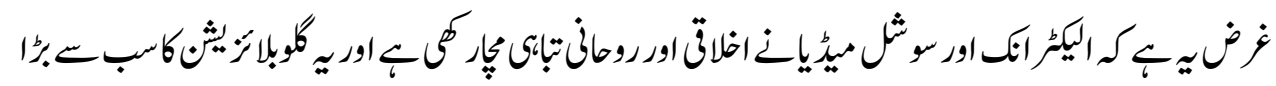

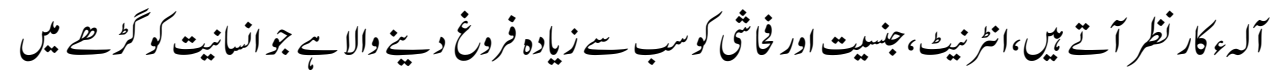

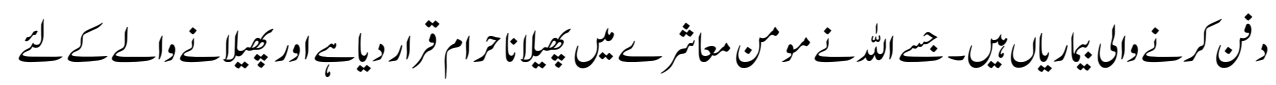

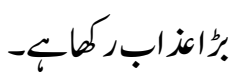

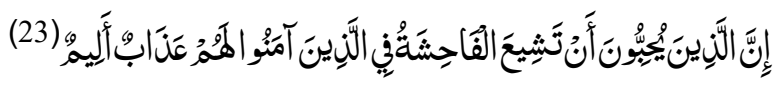

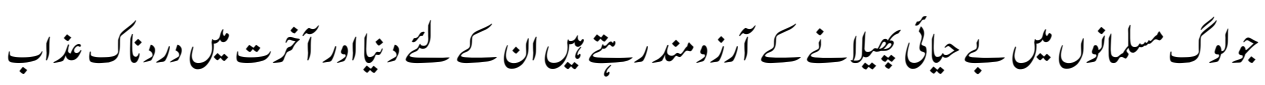

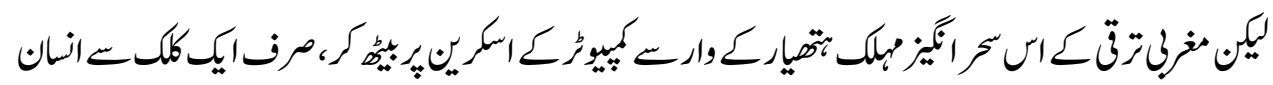

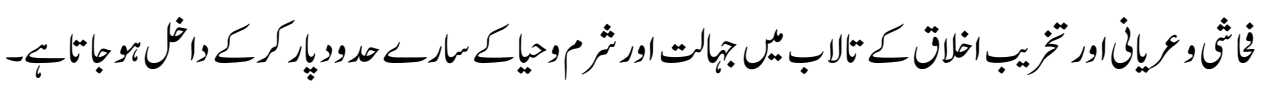

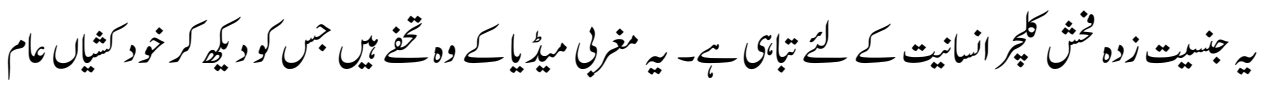

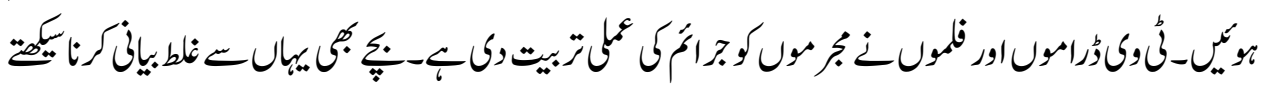

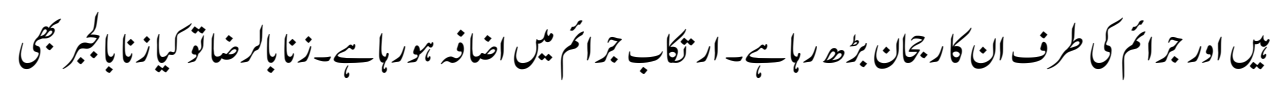

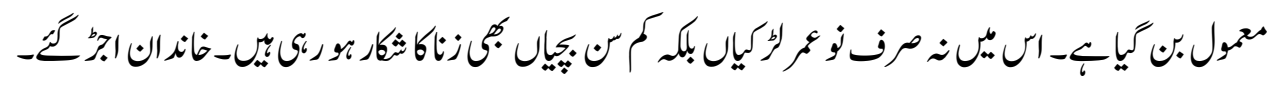

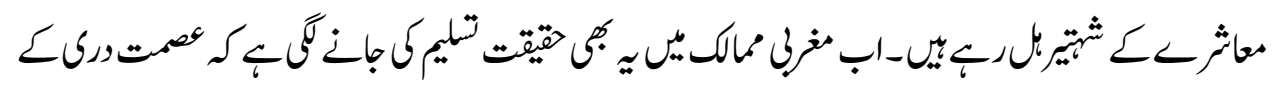

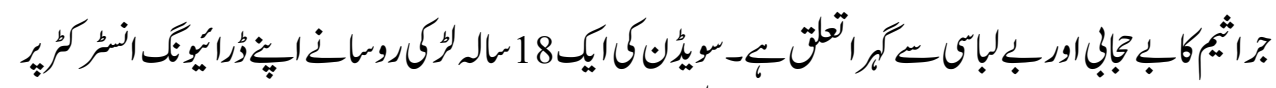

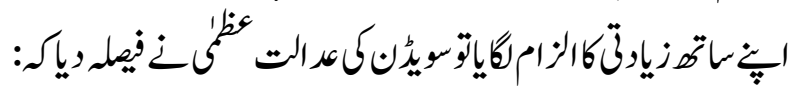




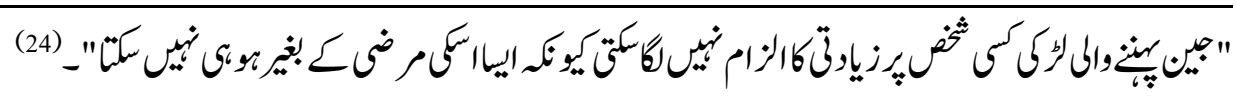

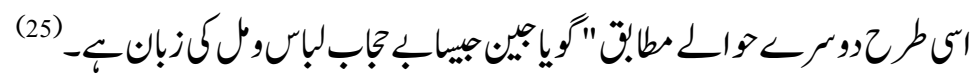

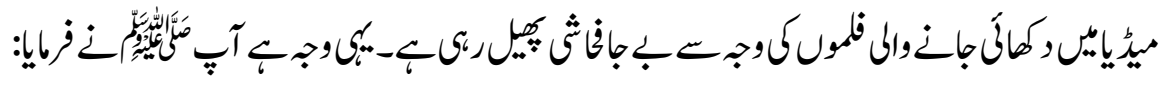

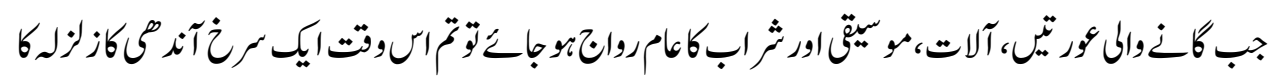

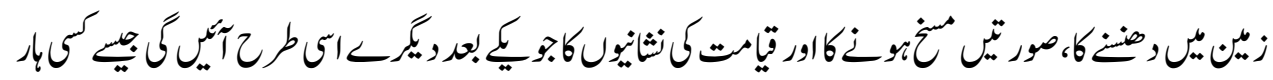

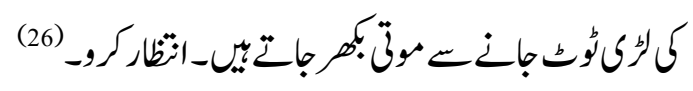

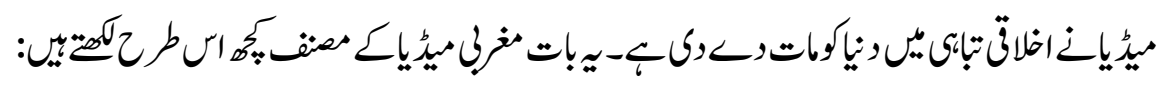

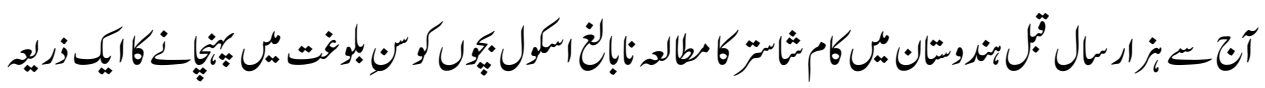

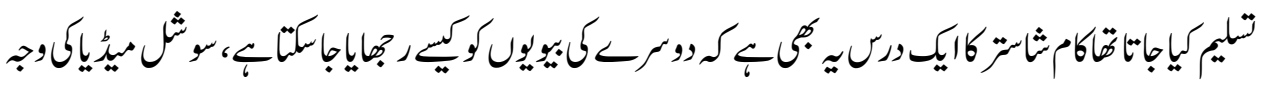

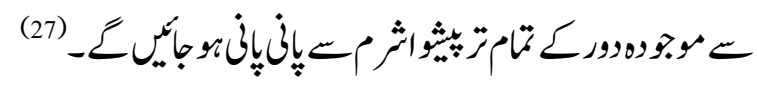

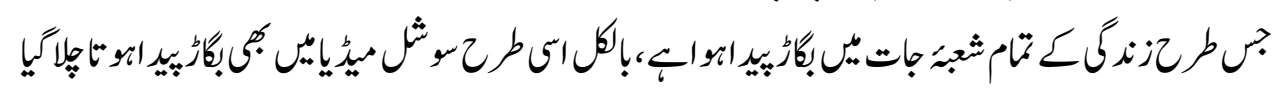

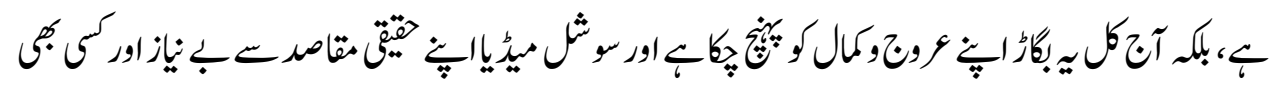

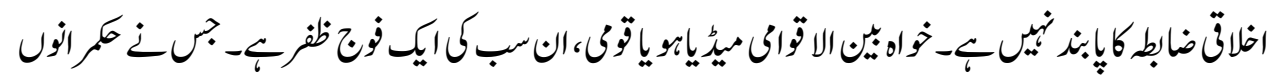

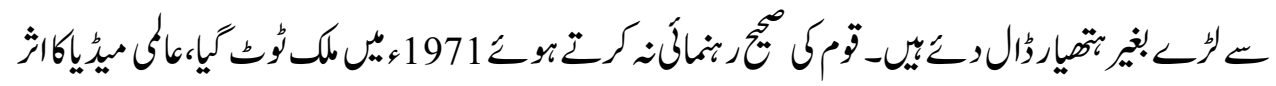

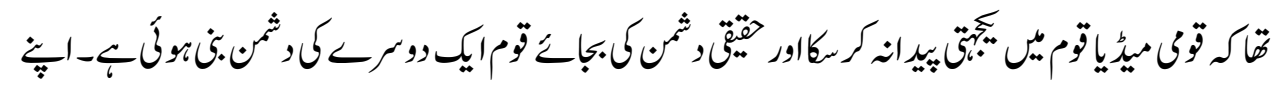

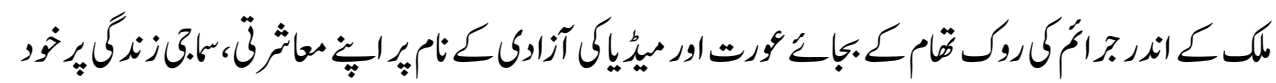

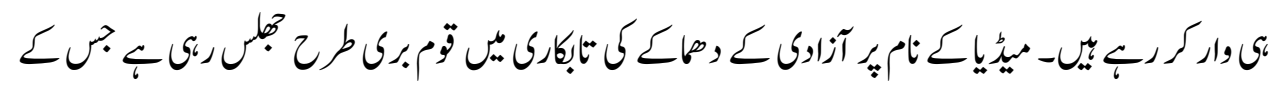

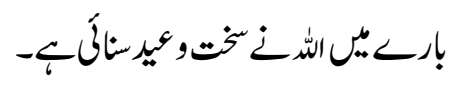

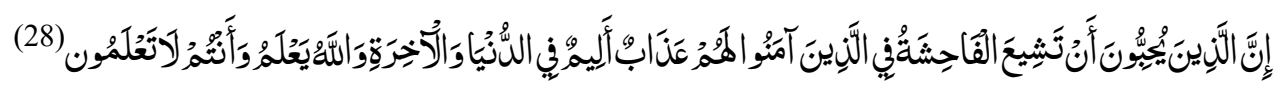

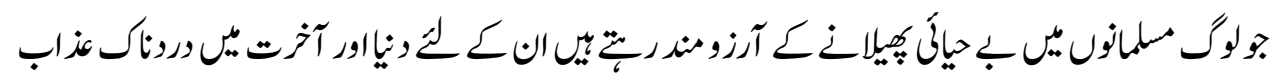

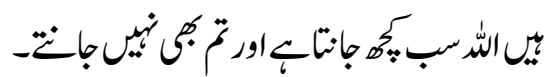

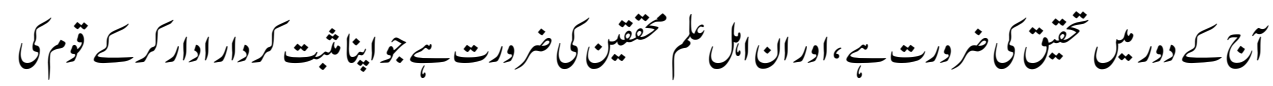

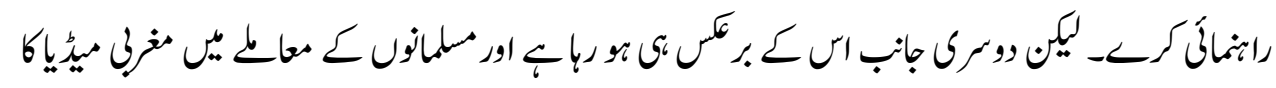

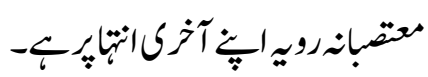




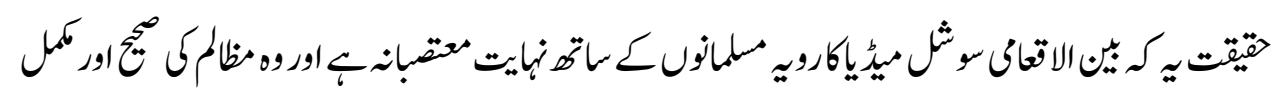

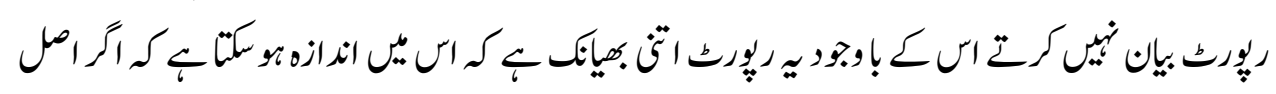

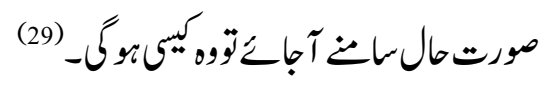

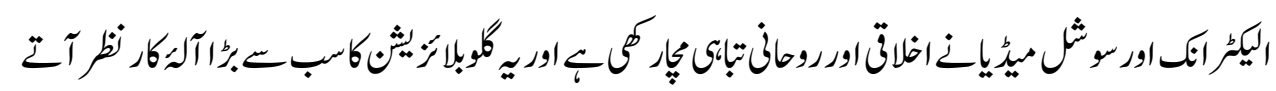

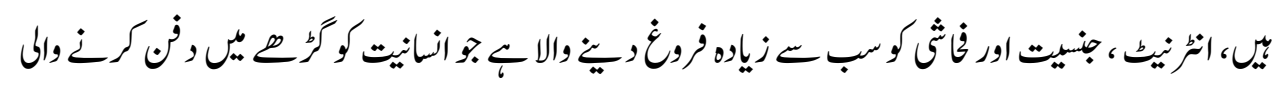

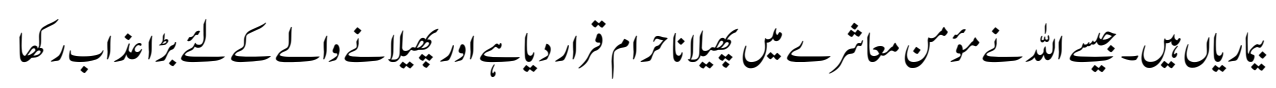

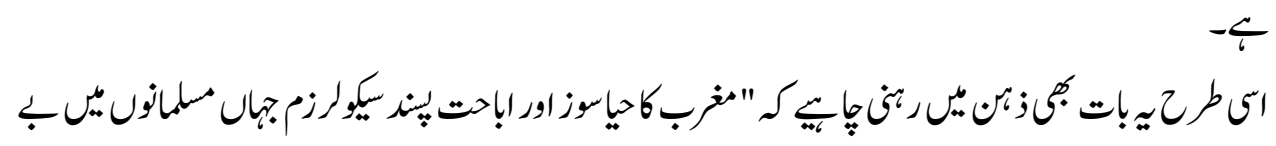

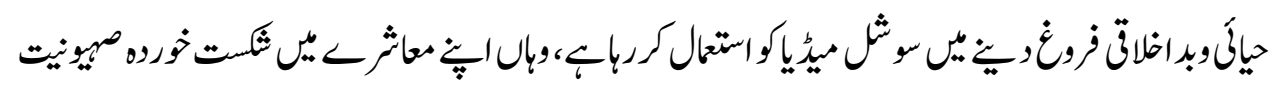

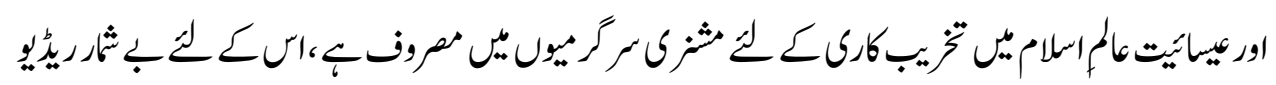

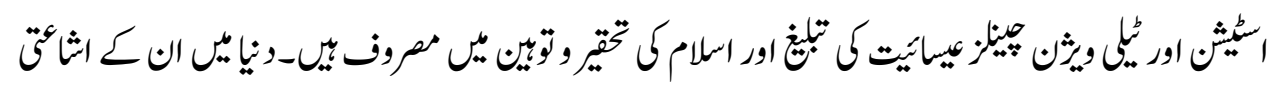

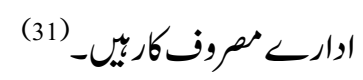

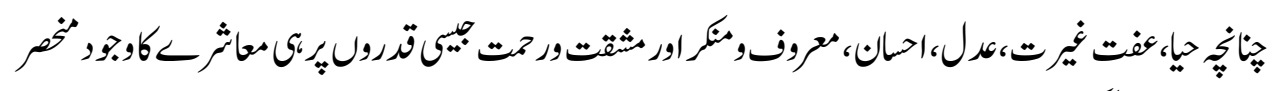

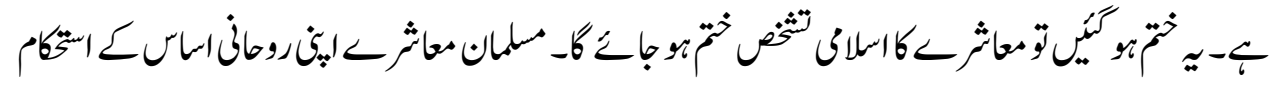

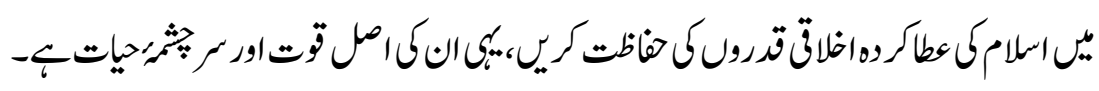

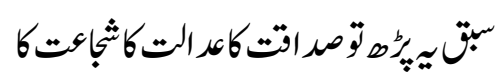

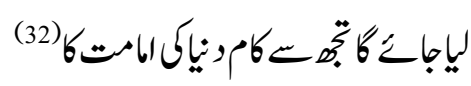

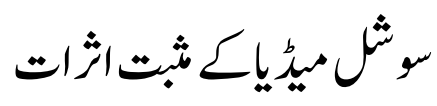

مئيإكارار

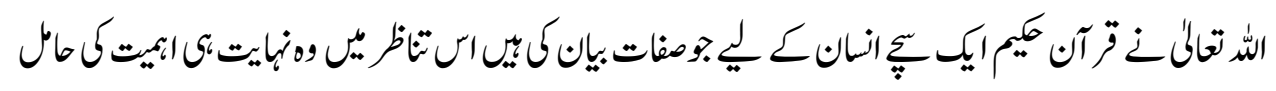

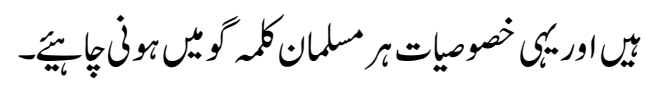

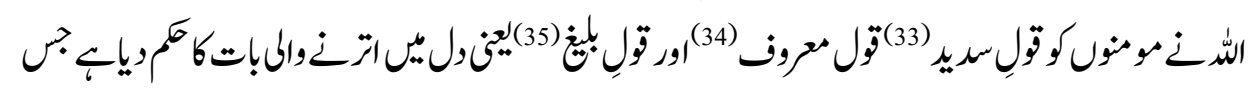




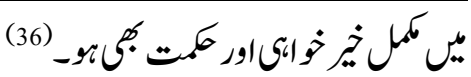

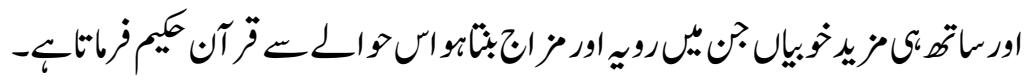

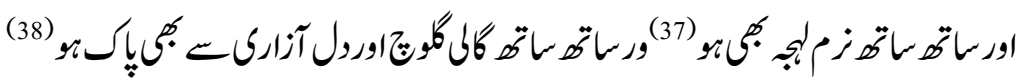

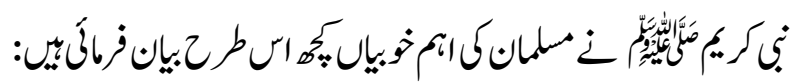

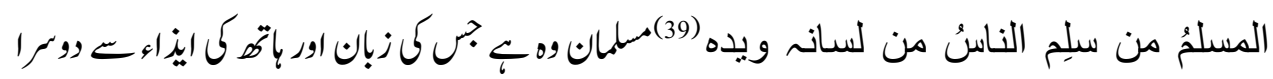

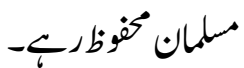

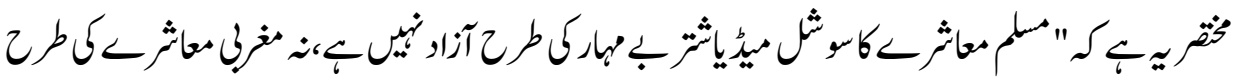

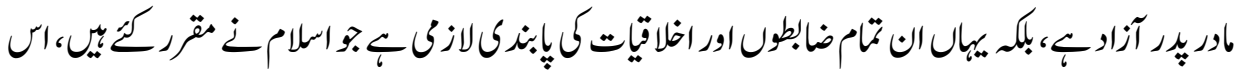

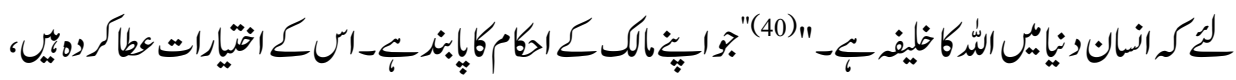

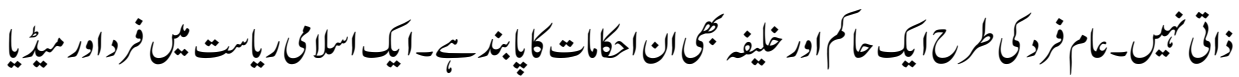

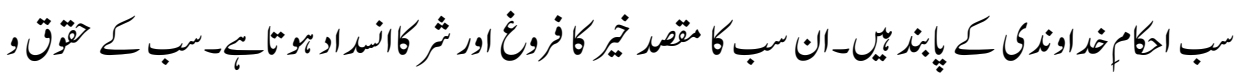

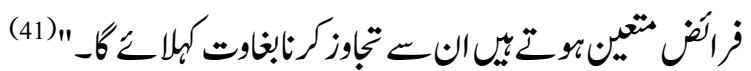

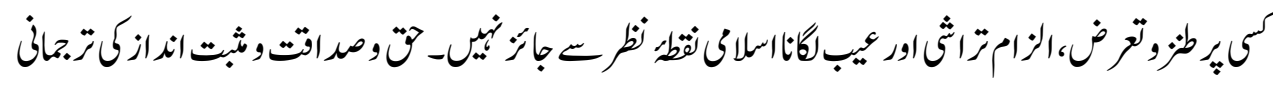

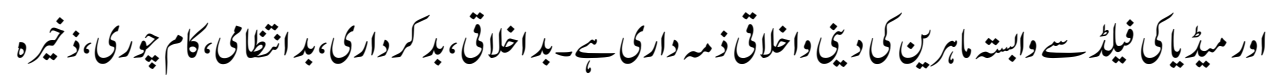

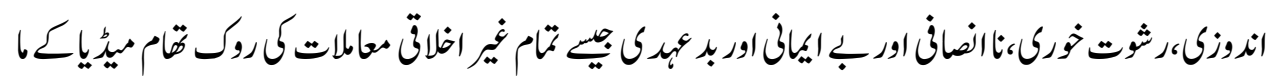

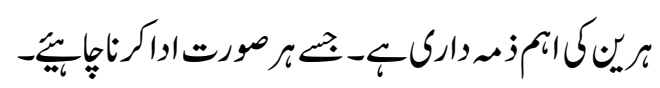
موَثناصحان مريتِكرا:

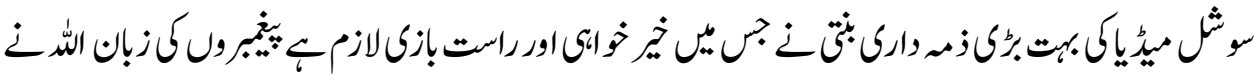

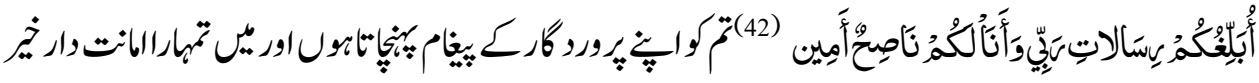
نوأون وبرك جَّه ارثارب:

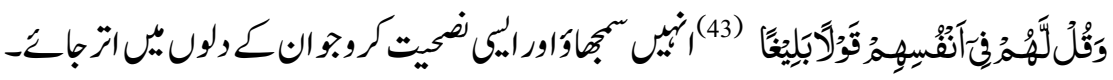




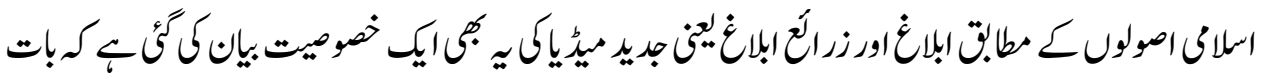

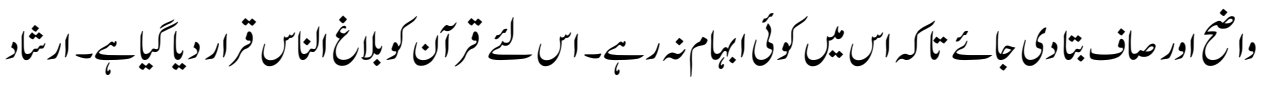

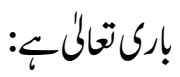

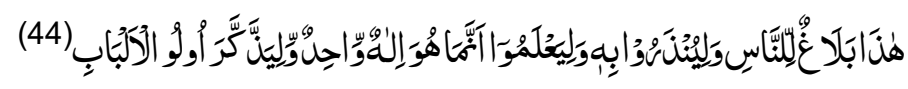

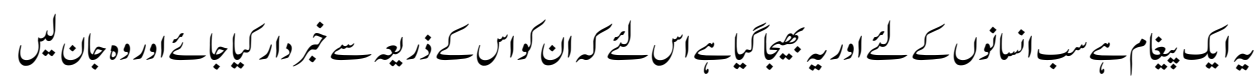

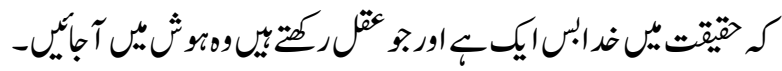

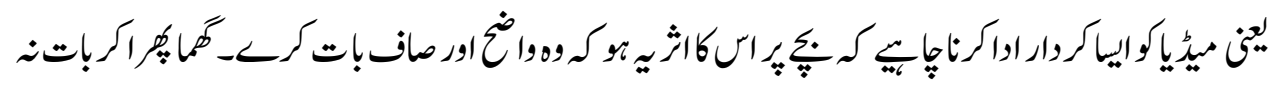

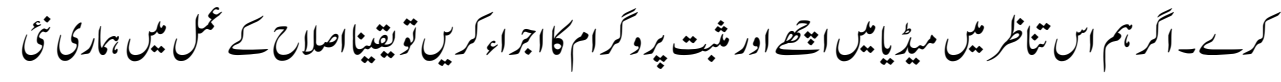

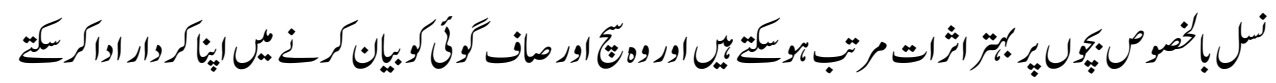

$$
\begin{aligned}
& \text { ثئ- }
\end{aligned}
$$

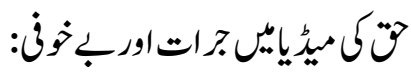

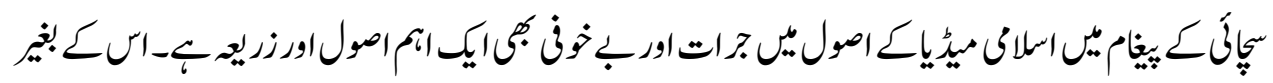

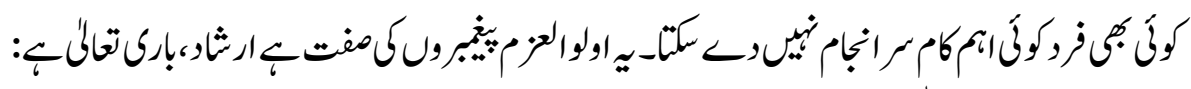

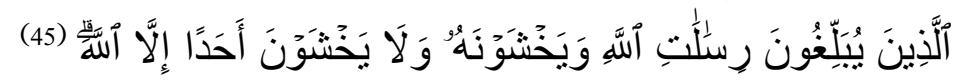

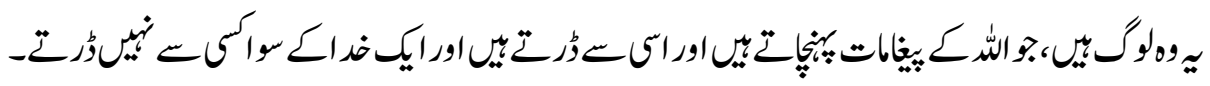

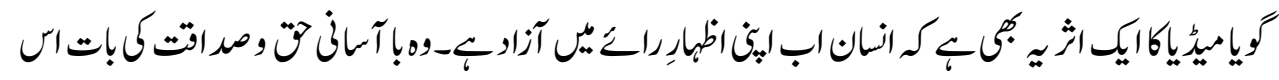

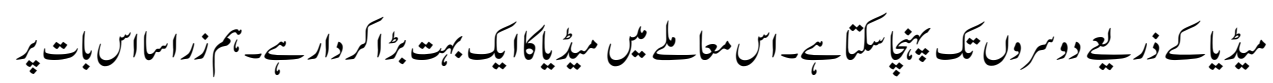

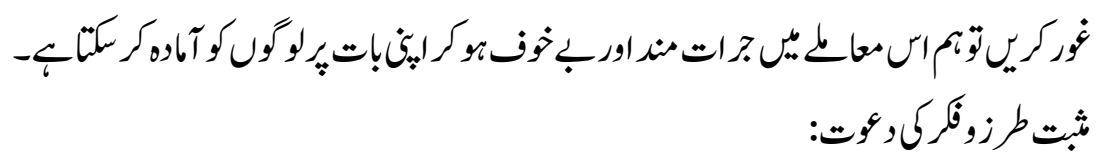

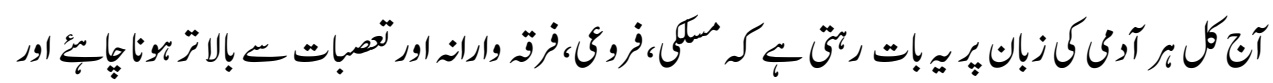

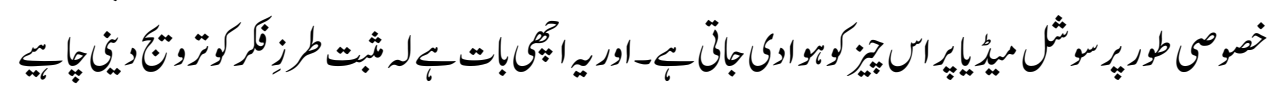

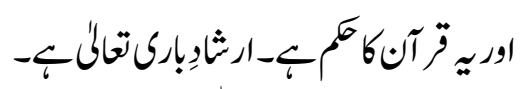

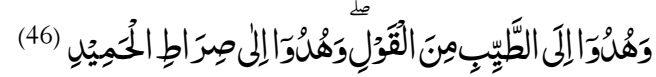




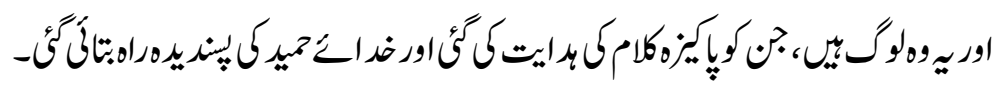

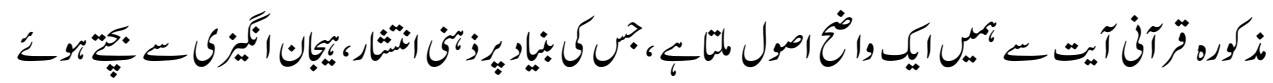

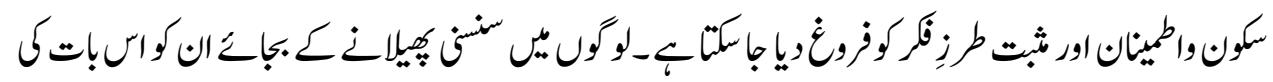

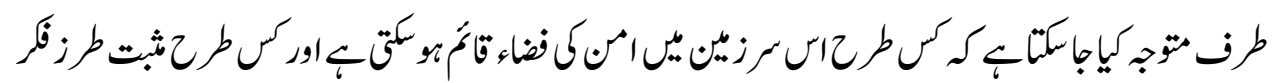

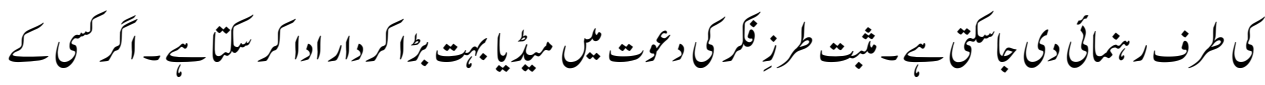

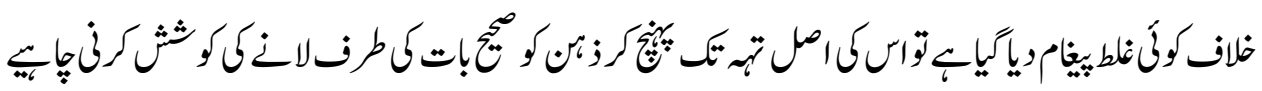

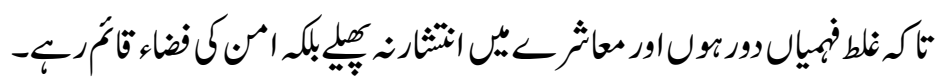

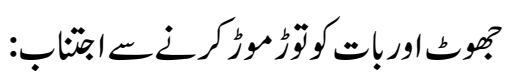

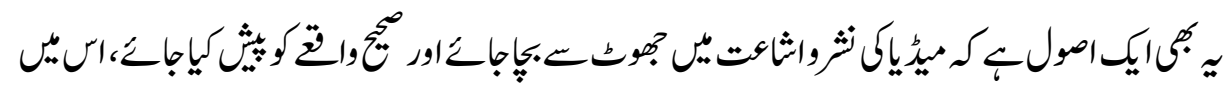

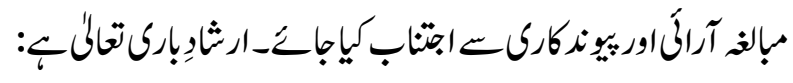

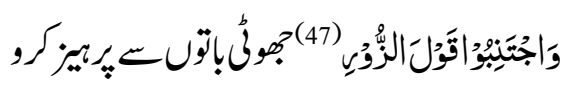

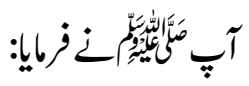

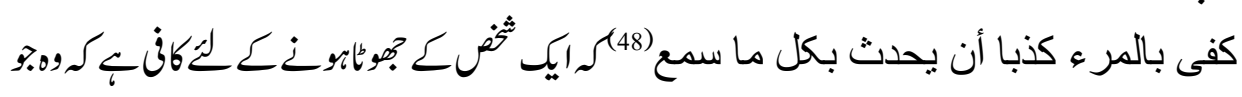

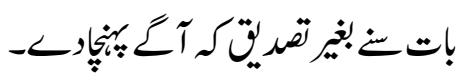

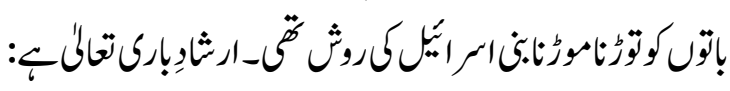

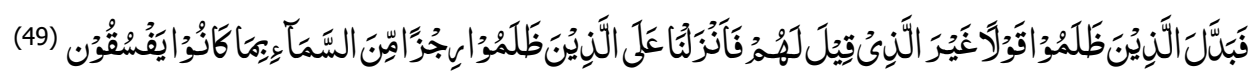

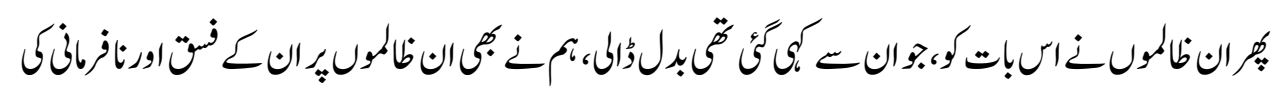

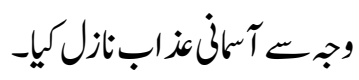

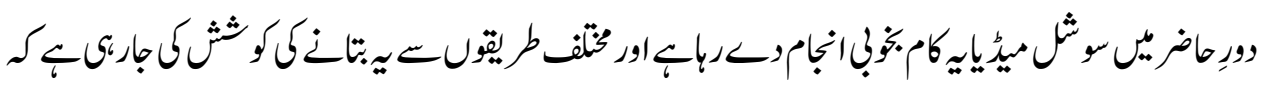

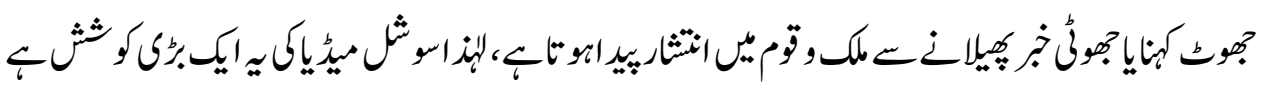

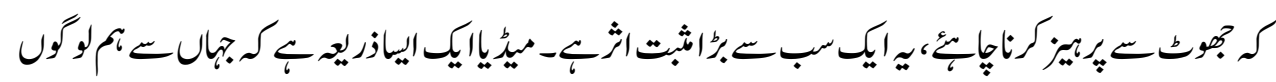

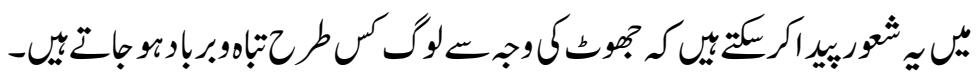

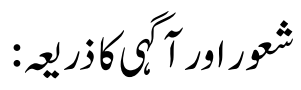




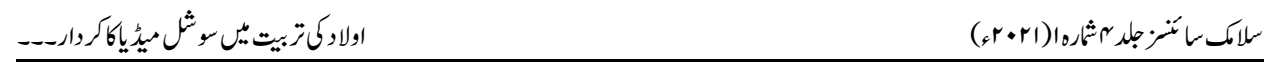

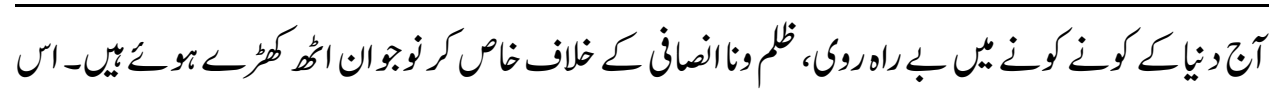

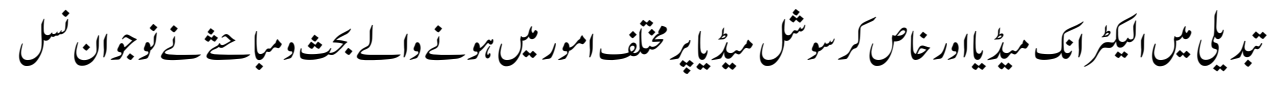

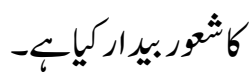

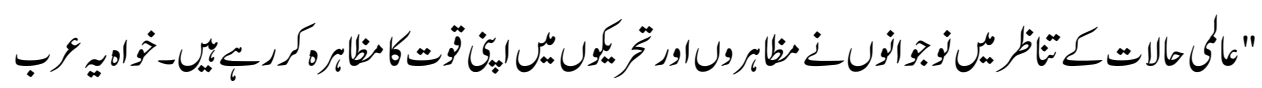

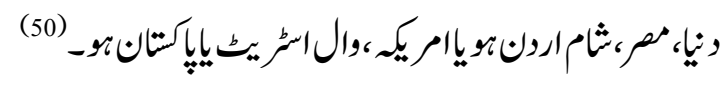

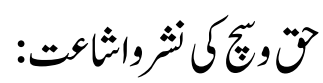

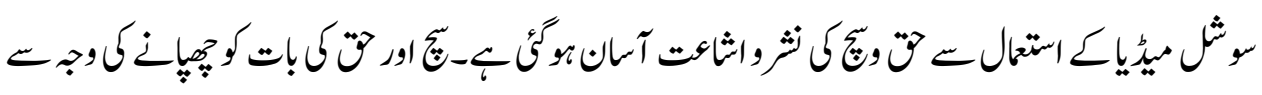

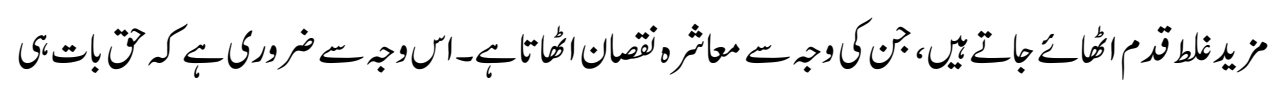

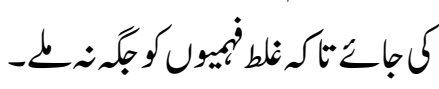

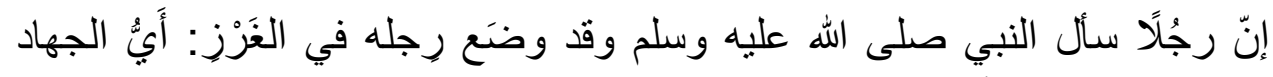

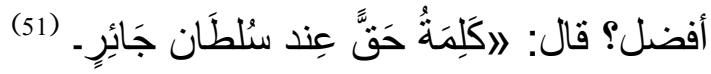

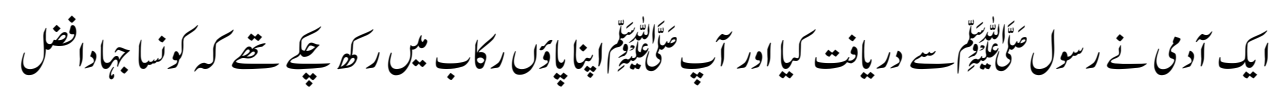

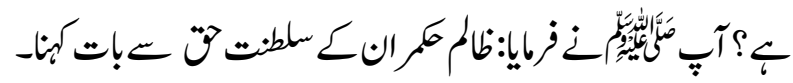

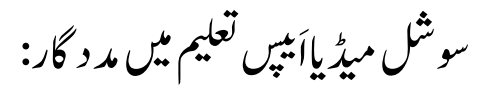

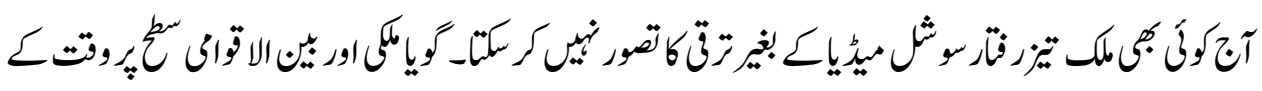

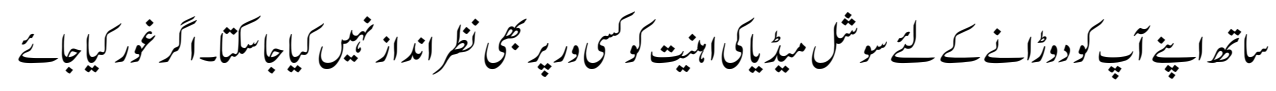

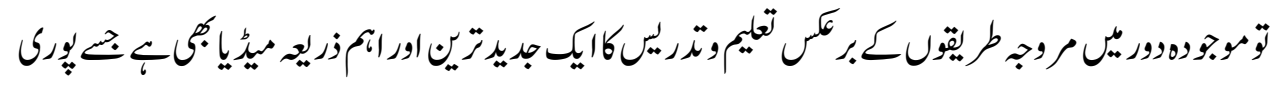

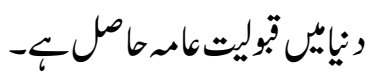
تهيم اورميُّيا:

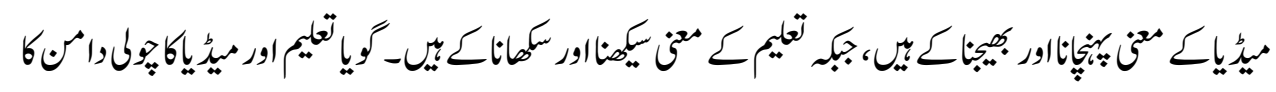

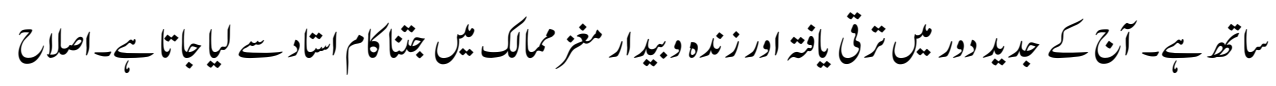

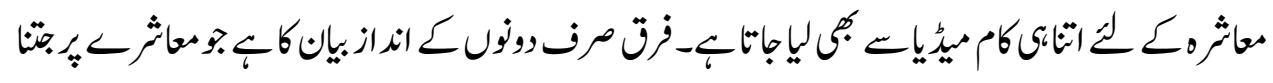

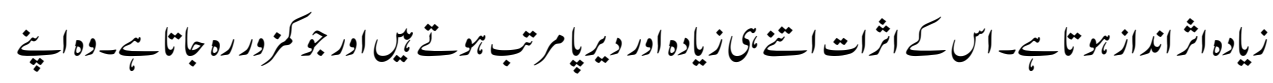




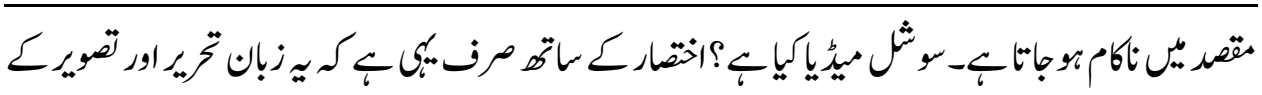

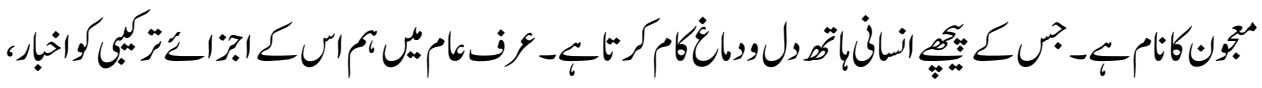

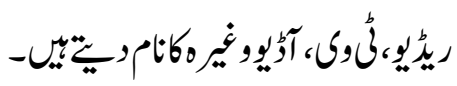

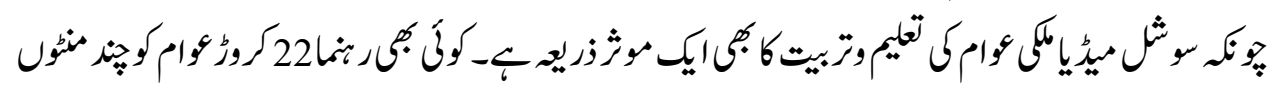

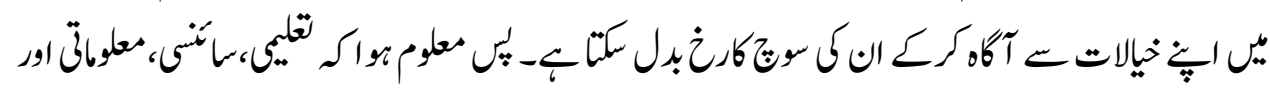

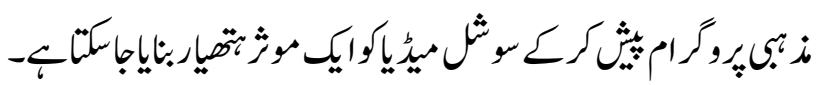

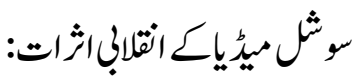

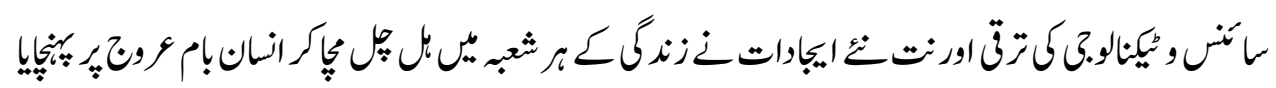

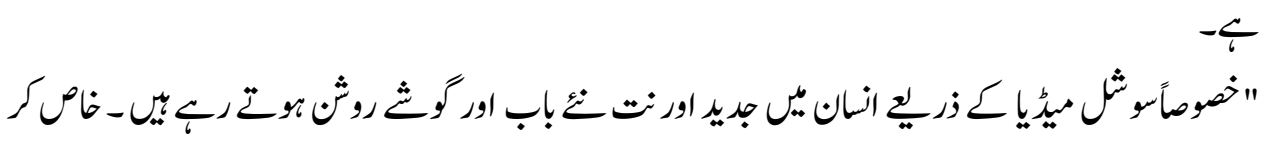

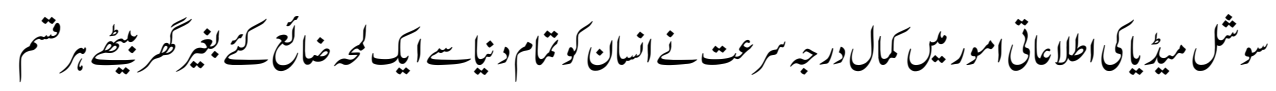

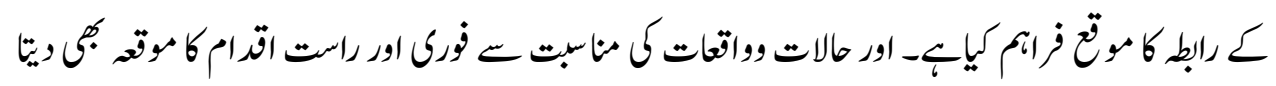

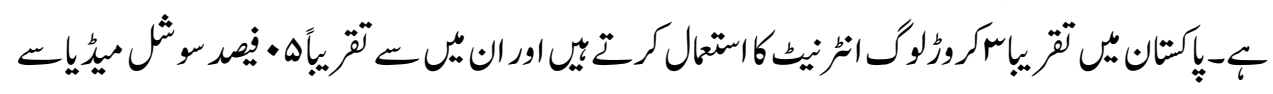

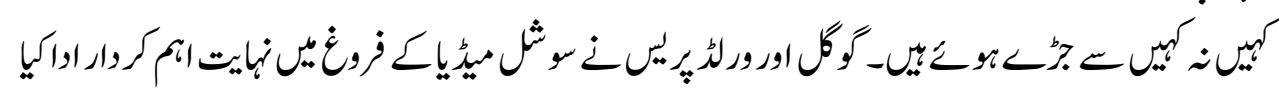

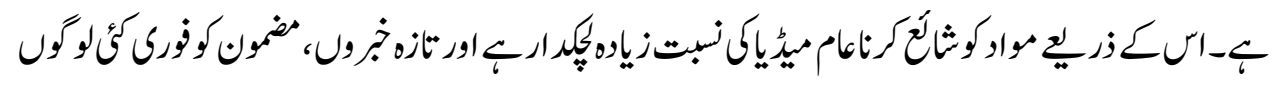

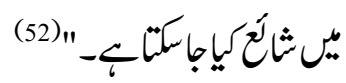

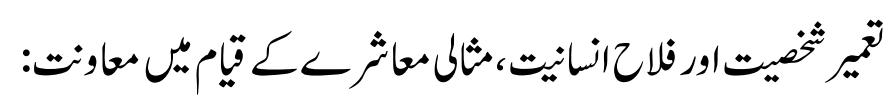

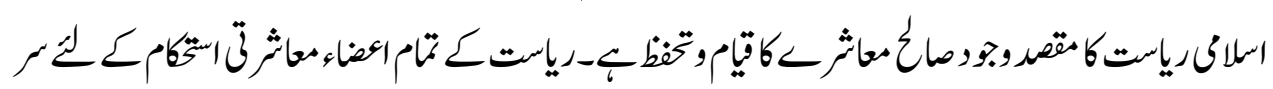

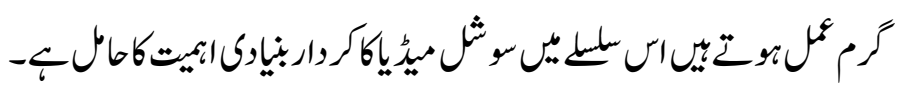

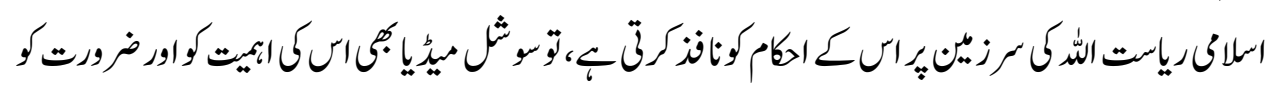

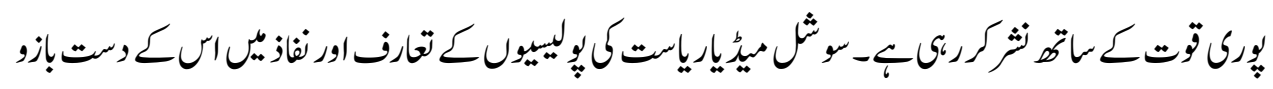

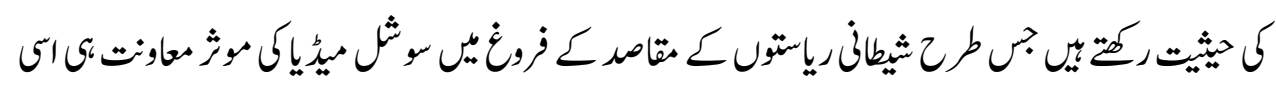

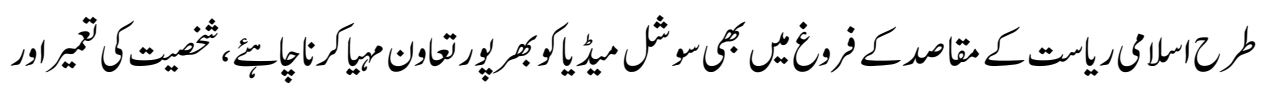




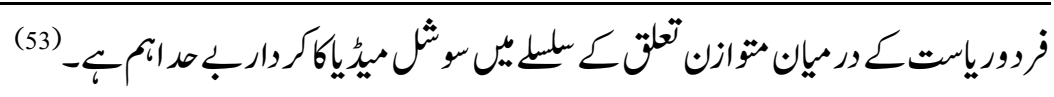

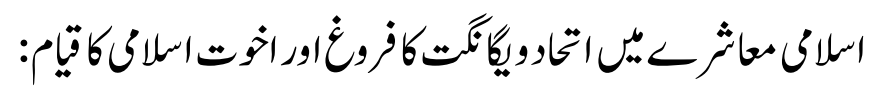

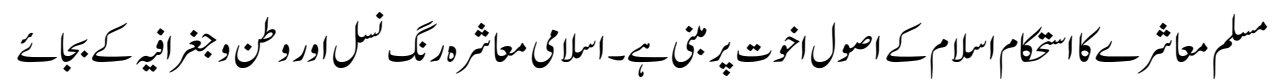

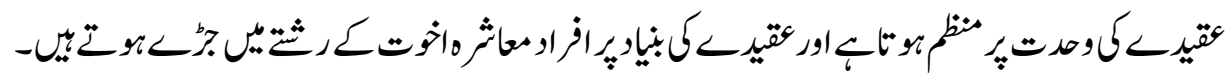

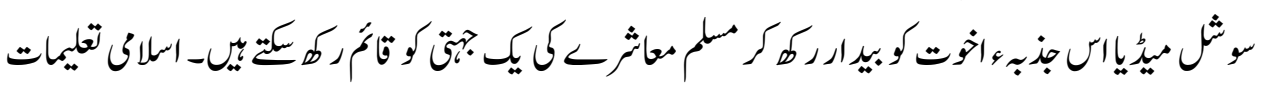

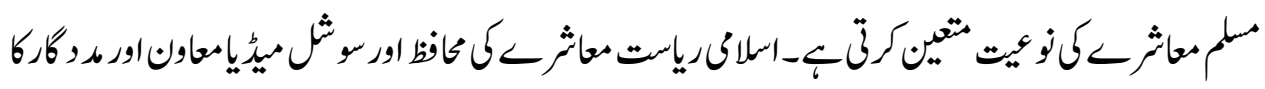

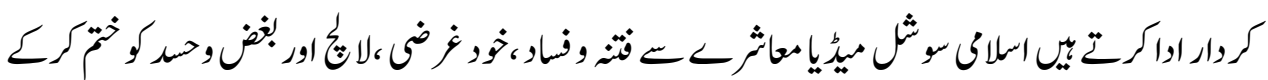

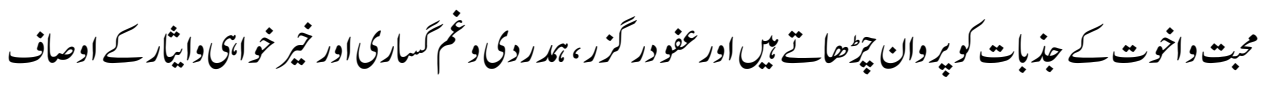

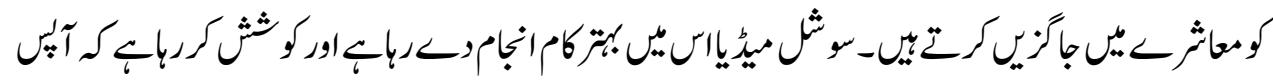

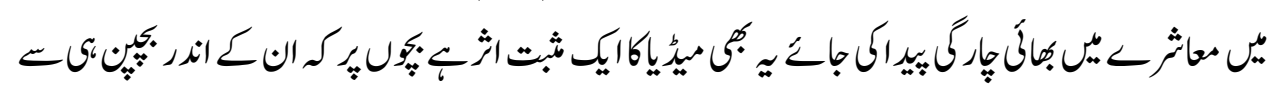

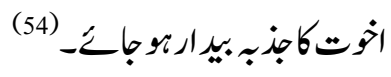
خلاص .كث:

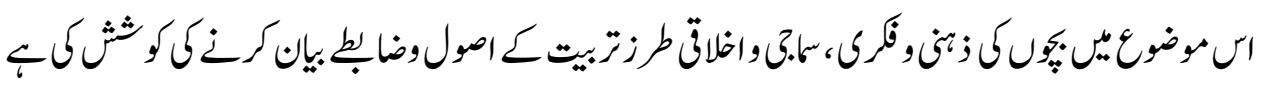

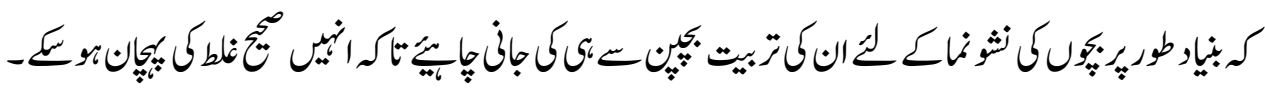

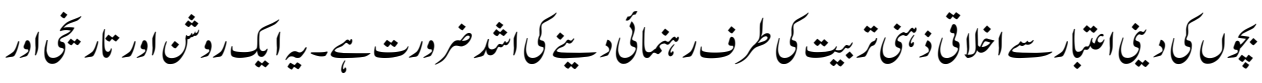

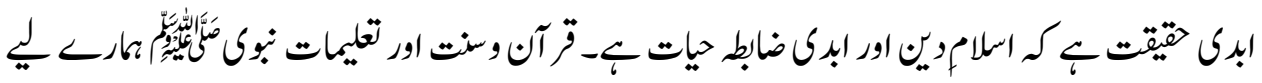

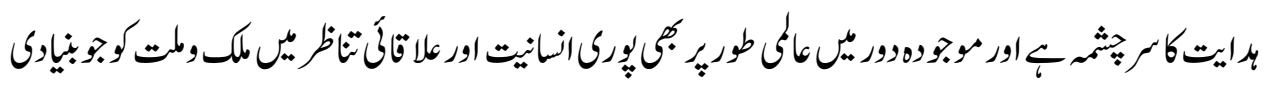

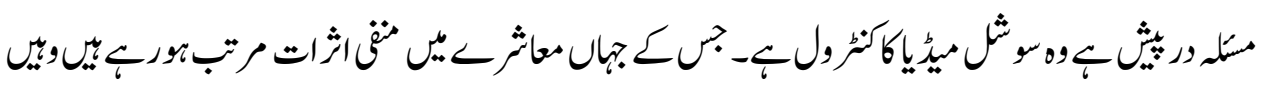

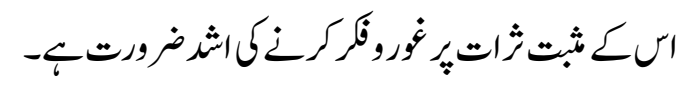

تجاويز:

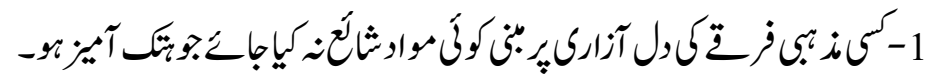

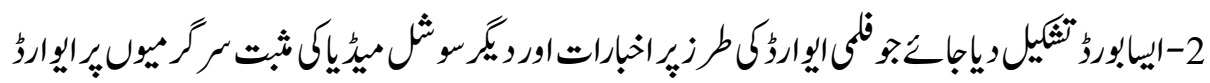
ريخكاسفارثكر 


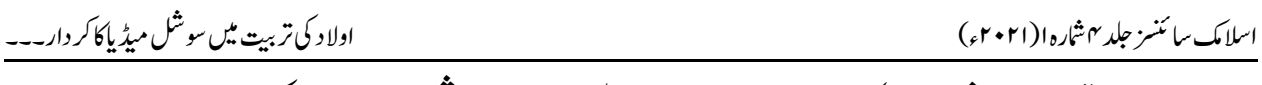

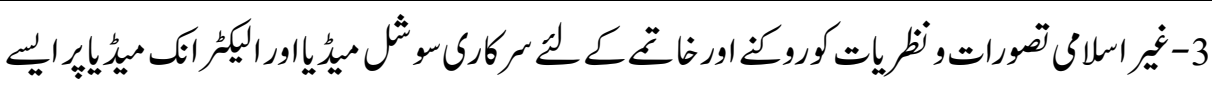

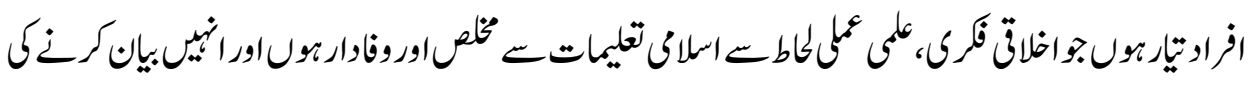

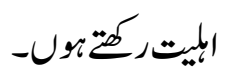

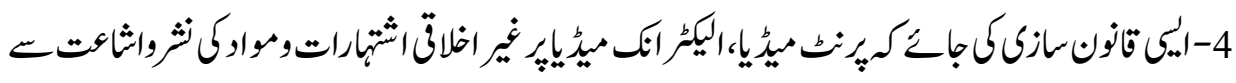
روكاجإسك-

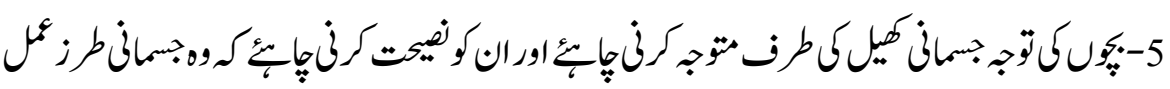

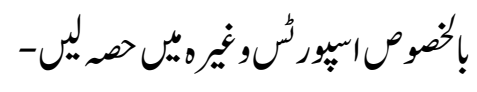

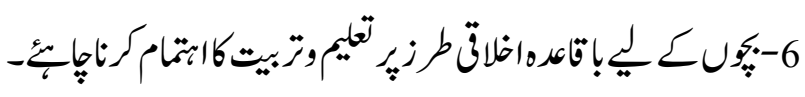
و الدجات:

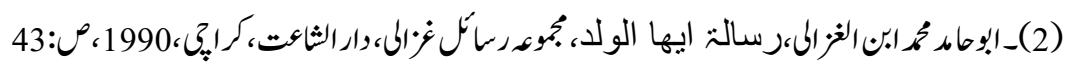

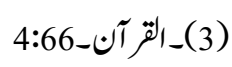

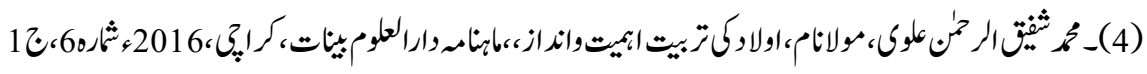

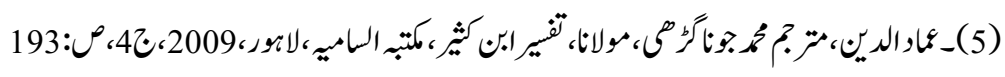

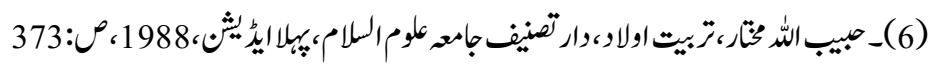

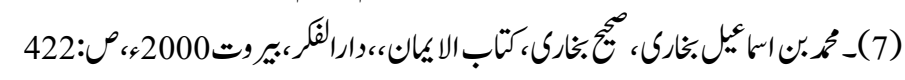

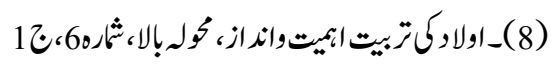

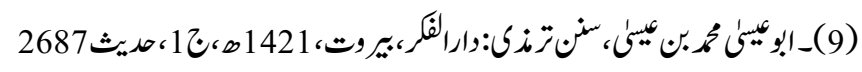

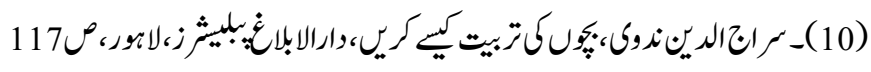

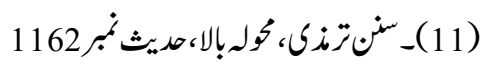

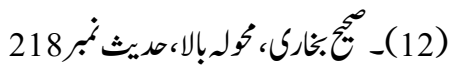

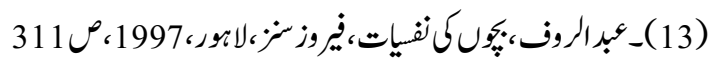

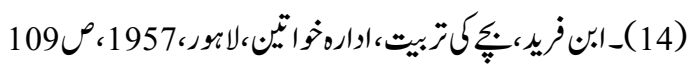

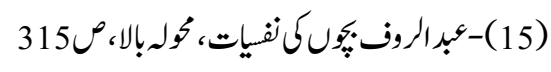

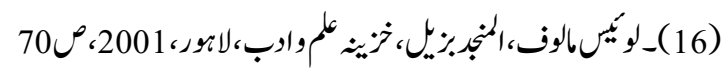

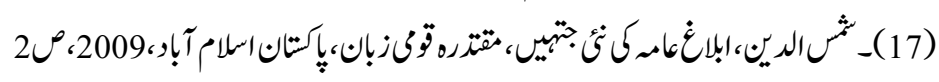


Emery, Alt, Introduction to mass Communication London, 1979, P 08 _(18)

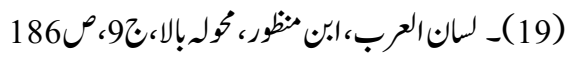

Collier's Encyclopedia, The Cornell-Collier Publishing Company,1963,13/642_(20)

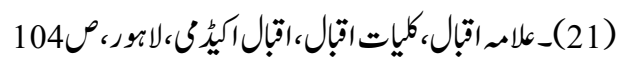

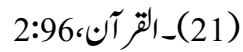

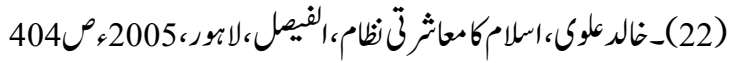

$$
\text { 91: 23) }
$$

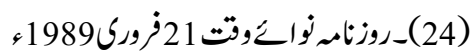

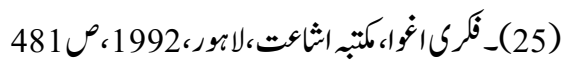

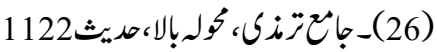

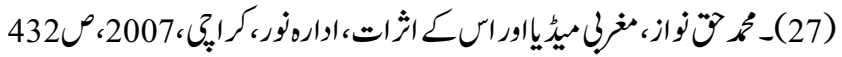

(28) - 2 (28) التر آن،النور:91)

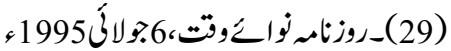

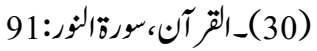

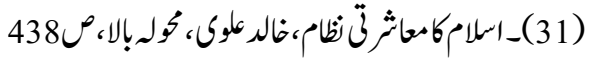

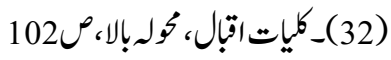

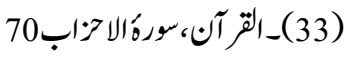

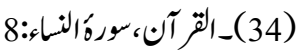

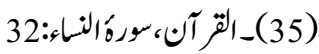

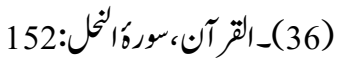

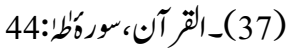

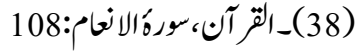

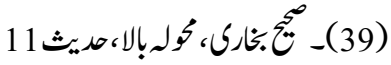

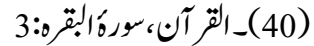

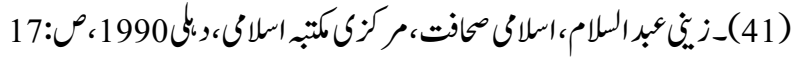

(42)_الت آن، أنورةالاؤاف:68

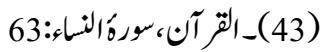

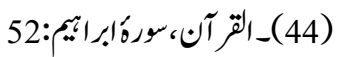




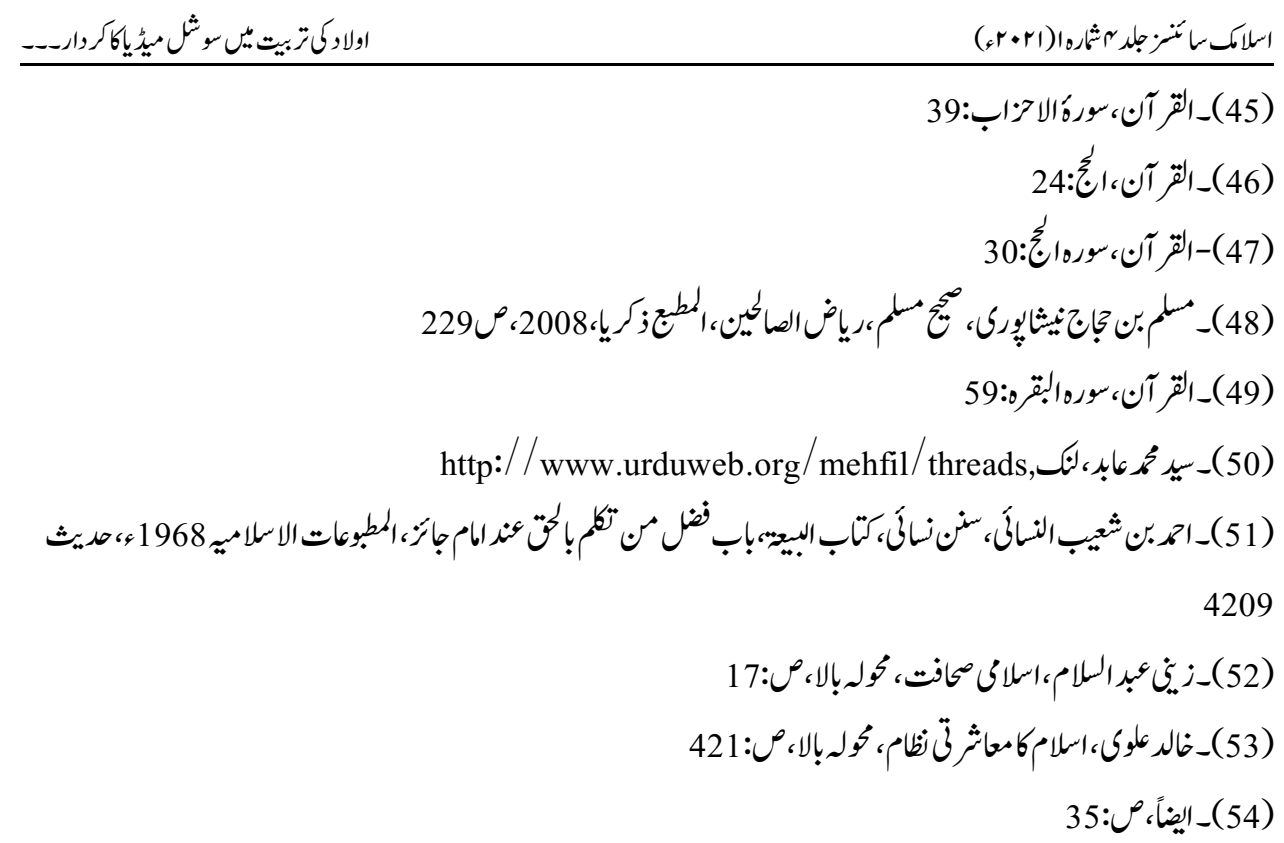

